\title{
U Şekilli Betonarme Perdelerin Farklı Yatay Yük Etkileri Altında Doğrusal Olmayan Davranışı
}

\author{
Halit Erdem ÇOLAKOĞLU ${ }^{1}$
}

Öz

Betonarme perde elemanları yatay yük etkisi altında kat yer değiştirmelerini sınırlandırması bakımından oldukça büyük öneme sahiptir. Deprem bölgelerinde hem yapının güvenliğini sağlamak hem de yer değiştirmeleri sınırlandırarak yapısal olmayan elemanlarda meydana gelecek hasarları azaltması bakımından etkili davrandıkları belirlenmiştir. Bu çalışmada sonlu eleman modeli yapılan U şekilli betonarme perdenin, on adet değişik yön ve değerdeki yatay yük etkileri altında doğrusal olmayan analizleri yapılmış, perdeye ait deformasyon şekilleri, yük-ötelenme eğrileri ve moment-eğrilik ilişkileri verilerek doğrusal olmayan davranışı araştırılmıştır.

Anahtar Kelimeler: U şekilli perde, eğilme, burulma, sonlu eleman analizi, modelleme, doğrusal olmayan davranış.

\begin{abstract}
Nonlinear Behavior of U Shaped Reinforced-Concrete Shear Walls Under Different Horizontal Loads

Reinforced-concrete shear walls have significant importance in terms of limiting floor displacements under the effects of horizontal loads. It has been determined that in earthquake zones reinforced-concrete shear walls are effective in increasing safety of a construction and decreasing the damage of non-structural elements by restraining displacements. In the current study, nonlinear behavior of $U$ shaped reinforced-concrete shear walls are investigated by performing nonlinear analysis under the effect of ten different types of horizontal loads. Deformation behaviors, load-displacement curves and moment-curvature relations of reinforced-concrete shear walls are also shown in the study.
\end{abstract}

Keywords: U-shaped shear wall, bending, torsion, finite element analysis, modeling, nonlinear behavior.

\footnotetext{
Not: Bu yaz1

- Yayın Kurulu'na 17 Ekim 2017 günü ulaşmıştır. 4 Temmuz 2018 günü yayımlanmak üzere kabul edilmiştir.

- 31 Mart 2019 gününe kadar tartışmaya açıktır.

- DOI: $10.18400 /$ tekderg. 344813
}

1 Giresun Üniversitesi, Keşap Meslek Yüksekokulu, Giresun - haliterdemcolakoglu@gmail.com 


\section{GİRIŞ̧}

Deprem açısından aktif bölgelerde yapılan yapılarda betonarme perdelerin kullanımı oldukça yaygındır. Betonarme perdeler yapıda deprem etkisi altında meydana gelecek burulma etkisini en aza indirmesi bakımından önemlidir. Burulma etkisinde yapının maruz kalacağ zararın boyutu perdelerin plandaki yerleşimi, kesiti ve daha birçok etkene bağlı olarak değişebilir. Bu nedenle betonarme perdelerin farklı yön ve değerlerdeki yatay yük etkileri altında incelenerek doğrusal olmayan analizlerle davranışlarının belirlenmesi günümüz yapı teknolojisinin gelişmesinde oldukça önemli bir paya sahiptir. Bu çerçevede yapı elemanları ve yapı sistemlerinin çeşitli yüklemeler altındaki davranışının incelenmesi için deneysel çalışmaların gerekliliği tartışılmazdır. Ancak, deneysel çalışmalara ait bilgisayar modellerinin oluşturulması ve model analizden elde edilen sonuçlar ile deney sonuçlarının karşılaştırılması yoluyla yapılan deneylerin tahkik edilmesi de sıkça karşımıza çıkmaktadır. Bu çalışmada, U şekilli betonarme perdenin sonlu eleman metodu ile modellemesi yapılarak farklı yön ve değerlerde yatay yük etkisi altında doğrusal ötesi analizleri yapılmıştır. Sonlu eleman analizlerinden elde edilen veriler, kesit analizi verileri ile karşılaştırılarak U şekilli perdelerin doğrusal olmayan davranışı araştırılmıştır.

Beton malzemenin yükleme altındaki (bir eksenli, iki eksenli ve üç eksenli) davranışı oldukça karmaşıktır. Çatlama, ezilme, gerilme sertleşmesi, basınç azalması, aderans yapışması gibi beton davranışları doğrusal olmayan malzeme modeli ile verilmektedir. Betonun doğrusal olmayan davranışının iki önemli sebebi; donatının plastik davranışı ve betonun yük altında çatlamasıdır. Çekme çatlağı betonun rijitliğini azaltır ve genellikle, iki eksenli çekme-basınç gerilmeleri taşıyan duvar, panel veya perde gibi elemanlar betonarme yapının doğrusal olmayan davranışını büyük oranda etkiler. Bu tür yapılar için betonun çatlama davranışını doğru modellemek, hiç şüphesiz ki en büyük zorluklardan biridir. Betonarme yapılarda eğilme momentinin küçük değerleri için betonda basınç ve çekme gerilmeleri meydana gelirken, donatı elastik davranır. Bütün beton kesiti davranışa etkili olduğu için donatının katkısı bu devrede sınırlı olur. Kesitin eğilme rijitliğine beton kesitinin elastiklik modülü ve brüt atalet momenti etkili olur. Momentin artmasıyla çekme bölgesindeki beton çatlar ve çatlak tarafsız eksene doğru ilerler. Betonun çatlaması moment-eğrilik değişiminde küçük de olsa ilk doğrusal davranıştan ayrılmayı doğurur (Şekil 1). $L_{0}$ anında betonarme kesitin dış çekme lifinde normal gerilme, eğilmedeki betonun çekme dayanımına eşit olunca betonda çatlaklar meydana gelir. $L_{0}$ çatlama noktasına karşı gelen $M_{c ̧ 0}$ eğilme momentinin hesabında beton kesitin homojen olduğu varsayılmakta ve betonun $\sigma-\varepsilon$ bağıntısı doğrusal elastik olarak alınmaktadır. Gerçekte betonun doğrusal olmayan davranışı artan gerilmelerle yavaş yavaş belirgin duruma gelir. $L_{1}$ anında betonun dış basınç lifinde veya çekme donatısında plastik şekil değiştirme başlar. Plastik şekil değiştirmelerin betonda $\varepsilon_{c 0}$ birim kısalmasında, çelikte ise $\varepsilon_{s y}$ akma sınırında başladığı göz önünde tutulmaktadır. Eğilme momenti artarken, beton basınç gerilmeleri dağılışı doğrusal olmayan bir değişimle oluşur ve donatı akma gerilmesine ulaşır. Momentin bu değeri $M_{y}$ akma momenti olarak bilinir. $M_{y}$ eğilme momentinin hesabında betonun çekme dayanımı hesaba katılmaz. $L_{2}$ anında eğilme momenti artarak kesitin taşıma kapasitesi adı verilen $M_{u}$ değerine eşit olunca basınç bölgesindeki beton ezilerek kırılır veya çekme donatısı kopar. Basınç bölgesindeki betonun 
ezilerek kırılması birim kısalmanın $\varepsilon_{c u}$ sınır değerine erişmesi suretiyle meydana gelir. Genellikle donatının uzama kapasitesi büyük olduğu için, güç tükenmesi betonun en büyük kısalma kapasitesine erişmesiyle ortaya çıkar ve kesit taşıma gücüne erişir [1].

a)
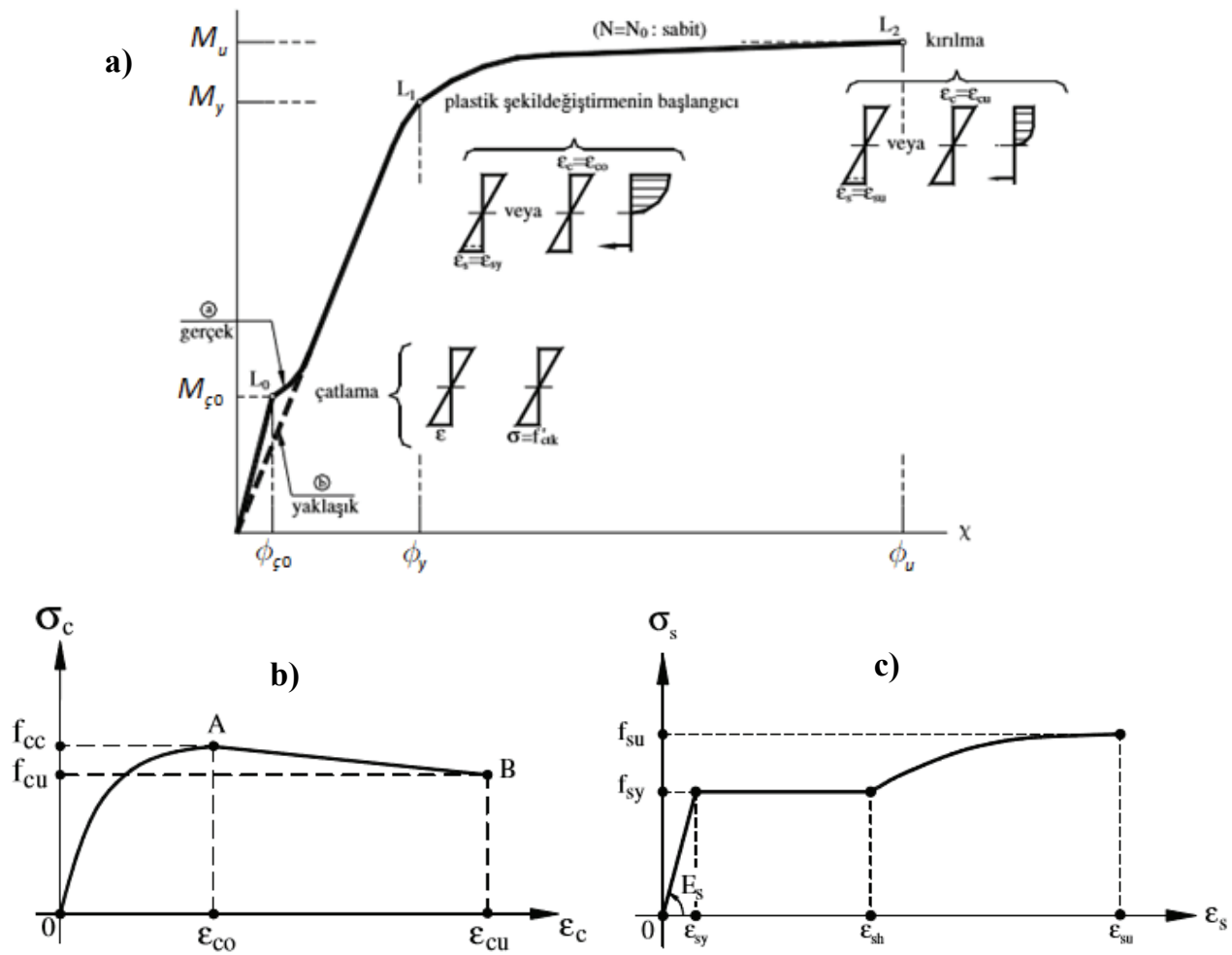

Şekil 1 - a) Betonarme Kesitte Ĕğilme Momenti-Ĕgrilik Iliş̧kisi b) Betonun Gerilme-Birim Şekil Değiştirme İlişkisi c) Beton Çeliğinde Gerilme-Birim Şekil Değiş̧tirme İlişkisi

Beyer ve diğerleri [2] yaptıkları çalışmada, ETH Zurih'de tamamlanmış bir deneysel programdan yola çıkarak, iki adet U şeklindeki perde yarı statik tekrarlı yüklemeye tabii tutmuşlardır. Bu çalışmada, bu iki adet deney sistemi için doğrusal olmayan geniş kolon modelleri geliştirilmiştir. Çalışma, literatürde bulunan tavsiyelere göre inşa edilmiş geniş kolon modellerinin analizi ile başlamaktadır. Bu tavsiyeler elastik sistemlerin analizi ile elde edilmiş olup, geniş kolon modellerinin doğrusal olmayan davranış üzerindeki etkileri farkı modelleme varsayımları yapılarak araştırılmıştır. Son olarak yapılan testlerden elde edilen deneysel sonuç ile sayısal sonuçlar karşılaştırılarak büyük doğrusal olmayan deformasyonlara maruz $U$ şeklindeki perdelerin geniş kolon modellerini kurmak için pratik öneriler verilerek çalışma sonlandırılmaktadır.

Brueggen ve diğerleri [3] yaptıkları çalışmada, altı katlı bir ofis binasında yer alan $\mathrm{T}$ şekilli perdelerin tasarımında karşılaşılan sorunları araştırmışlardır. Bu sorunlar, iki eksenli 
yükleme durumunda bir kat seviyesindeki perdeler arasındaki kuvvet dağılımını ve ACI 31802 [4] ye göre perdelerin detaylandırılmasını içermektedir. Yapılan çalışmalar $\mathrm{T}$ şekilli perdelerin tasarımının dikdörtgen şekilli perdelerin tasarımında kullanılan yöntemlere benzer yöntemler kullanılarak yapılabileceğini göstermiştir.

Maruta ve diğerleri [5] yaptıkları çalışmada, aynı anda yatay yük ve burulmaya maruz kalan $\mathrm{H}$ şekilli betonarme perdelerde deneysel ve analitik çalışmalar yapmışlardır. Burulma dayanımının, bir tarafı açık (OSCW) olan perdelerde, kapalı olanlara (CSCW) göre daha az olduğunu belirlemişlerdir. Bu durumda OSCW perdelerde elasto-plastik kapasitenin, CSCW perdelere göre daha az olduğunu tahmin etmişlerdir. Yapılan bu çalışmada dokuz adet $\mathrm{H}$ şeklindeki perde, aynı anda yatay yük ve burulma altında test edilmiş, yatay yük ile $\mathrm{H}$ şeklindeki duvarın yatay yük yönündeki burulma oranı incelenmiştir. Tüm örnekler, H şekilli betonarme perdelerin öncelikle eğilme mukavemetine ulaşması böylece kesmeden kaynaklı deformasyonların iyi bir şekilde gösterilmesi için tasarlanmıştır. Doğrusal olmayan sonlu eleman analizleri test sonuçlarını doğrulamak ve denenmemiş durumların verilerini elde etmek için yapılmıştır.

Wallace ve Moehle [6] yaptıkları çalışmada, betonarme perdelerin deprem performansının belirlenmesi için perdelerde deprem sonucu oluşan ötelenme talebi ve mevcut kapasiteyi karşılaştırarak perde uç bölgesinde gerekli olan süneklik ve donatı detaylandırmasını incelemiş, deprem etkisine maruz kalmış binalardaki betonarme perdelerin donatı gereksinimlerini belirlemek adına analitik bir yöntem kullanmıştır.

Abdulkerim ve Atımtay [7] yaptıkları çalışmada, tünel kalıp tekniği ile inşaa edilen çok katlı yapıların deprem yükleri altındaki dayanım ve davranışlarını araştırmışlardır. Bu amaçla, tünel kalıp teknolojisi uygulamalarında yatay elemanlar olan döşemeler ile düşey elemanlar olan perdelerin birleşim bölgelerinden oluşan bir kesit modellemişlerdir. Modellenen yap1 sistemi, Selçuk Üniversitesi, Mühendislik-Mimarlık Fakültesi, İnşaat Mühendisliği Bölümü Yapı Laboratuarında çelik profillerden imal edilmiş yatay yük çerçevesinde tersinirtekrarlanır yük altında denenmiştir. Modeller üzerindeki tersinir-tekrarlanır yatay yük uygulaması; perde ve döşeme boyutları sabit olmak üzere, perdelerdeki donatı miktarlarına ait parametreler değiştirilerek 4. kat, 3. kat ve 2. katlardan uygulanmıştır. Betonarme perdelerde yatay ve düşey donatı aralıklarının etkisinin belirlenmesi için TGPA, TGPB ve TGPC olmak üzere üç çeşit model üzerinde deneyler yapılmıştır. Numunelerde kullanılan donatı düzenine göre moment-eğrilik, yük-şekil değiştirme ve perde tabanında meydana gelen yük-ötelenme grafikleri hazırlanmıştır. $\mathrm{Bu}$ değerler kendi içlerinde ve teorik araştırmadan elde edilen sonuçlarla karşılaştırılmıştır. Ayrıca perde kesitinin, yerleştirilen donatıların kopma anındaki moment kapasiteleri deneysel ve teorik olarak irdelenerek çalışma sonlandırılmıştır.

Ormancı ve Saygun [8] yaptıkları çalışmada, betonarme perdelerin anizotropik malzeme davranışı esas alınarak çözümlendiği bir sonlu eleman geliştirilmişlerdir. Çözümde sonlu elemanın, kesitte çekme veya basınç bölgesinde kalmış olmasına göre, farklı eleman rijitlik matrisleri kullanılmıştır. Betonarme perde modelinin yatay yükler altında doğrusal olmayan davranışı incelenmiştir. Bu davranış çubuk sistemlerdeki plastik mafsal hipotezinin benzeri olarak, düğüm noktaları arasında sonlu elemanın doğrusal elastik davrandığı, plastik şekil değiştirmelerin düşey plastik yer değiştirmeler olarak düğüm noktalarında toplandığı kabulü ile tanımlanmıştır. Bu kabule göre betonarme perdede plastikleşme, düşey doğrultudaki birim şekil değiştirmenin, elastik şekil değiştirme sınırına erişmesi ile gerçekleşir. Sonlu elemanın 
tanımında perdenin sadece kat hizalarında bölünmesinin, çözüm için yeterli olduğu yer değiştirme fonksiyonları seçilmiştir. Çalışmada elde edilen sonuçlar farklı bir bilgisayar programı ile elde edilen çözümler ve deney sonuçları ile karşılaştırılmıştır.

\section{MATERYAL VE YÖNTEM}

$\mathrm{Bu}$ çalışmada, 8 katlı $24 \mathrm{~m}$ yüksekliğinde, taşıyıcı sistemi perdeli-çerçeveli olarak tasarlanmış, kolonları $50 \times 50 \mathrm{~cm}$ boyutlarında olan, 1.derece deprem bölgesinde yer alan ve yerel zemin sınıfı, DBYBHY-07 [9]' ye göre Z4 olarak belirlenmiş bir bina kullanılmıştır. Binanın taşıııı sistemi içerisinde bir adet $\mathrm{U}$ şekilli betonarme perde de mevcuttur. Mevcut binanın SAP2000 programında eşdeğer deprem yükü analizi yapılarak, U şekilli betonarme perdenin aldığı toplam kesme kuvveti ve eksenel kuvvet ile eğilme ve burulma momentleri belirlenmiş̧tir. Perdenin donatı hesabı SAP2000 programı bünyesindeki yapılmışıtır. Bunun için eşdeğer deprem yükü analizinden belirlenen eksenel kuvvet değeri kullanılarak, perdenin moment-eğrilik ilişkisi çizilmiştir (Şekil 2). Perdede Şekil 3'de gösterilen donatılar kullanıldığında oluşan moment taşıma kapasitesi $\mathrm{M}$, eşdeğer deprem yükü analizinden elde edilen maksimum moment değerinden büyük olduğundan kesit donatı durumu yeterlidir.

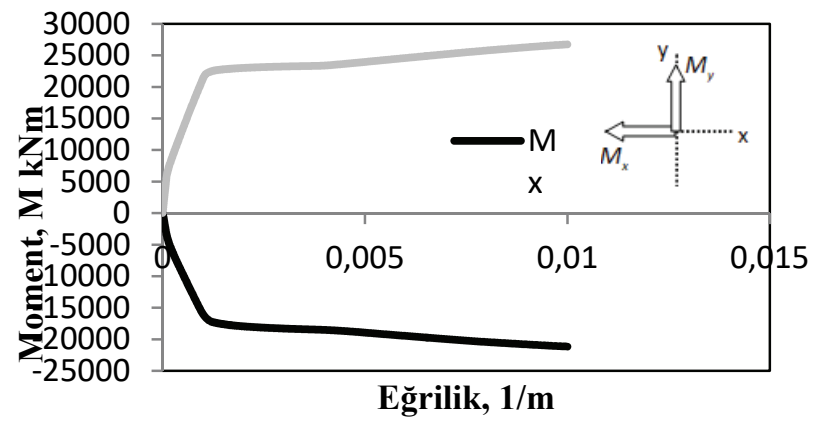

Şekil 2 - Kesit Analizinden Elde Edilen Moment-Ĕgrilik İlişkisi

Perde modelinin kol uçlarında ve gövde-kol birleşim bölgelerinde boyuna $\$ 26$ donatı, kol ve gövde ortasında boyuna $\phi 10 / 200 \mathrm{~mm}$ donatı kullanılmıştır. DBYBHY-07 [9]'ye göre düşey doğrultuda etriye ve/veya çiroz aralığı perde kalınlığının yarısından ve $100 \mathrm{~mm}$ 'den fazla, 50 mm'den daha az olmayacağından, hesaplarda etriye olarak $\phi 8 / 100 \mathrm{~mm}$ donatı tercih edilmiştir. Sonuç olarak bu çalışmada incelenen perde elemanların DBYBHY-07 [9]'ye göre süneklik düzeyi yüksek elemanlar olduğu söylenebilir. 


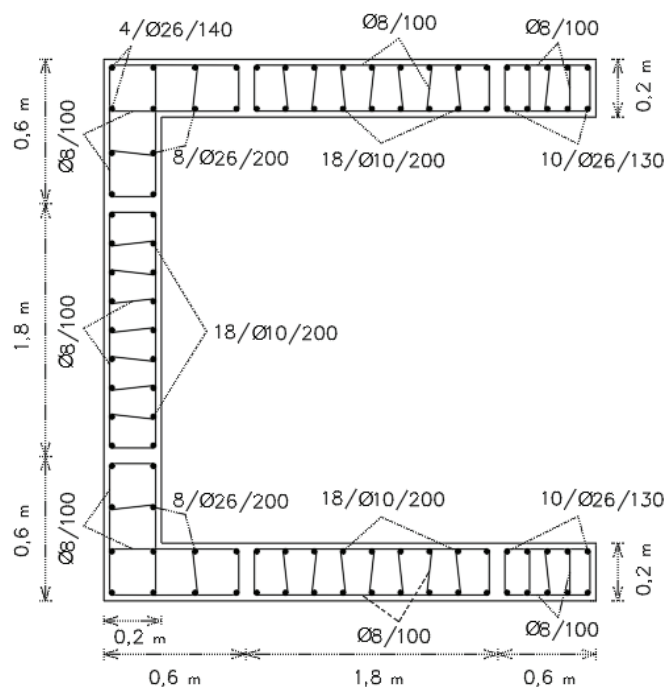

Şekil 3 - U Şekilli Perdenin Donatı Planı

DBYBHY-07 [9]'ye göre perde uç bölgesinin uzunluğu $\ell_{u}$, perdenin toplam uzunluğu $\ell_{w}$ 'nin 0,2 katına eşit ya da daha büyük olmalıdır. Bu nedenle $U$ şekilli betonarme perdenin uç ve gövde-kol birleşim kısımlarındaki sargı bölgesi $0,2 \ell_{w}$ olarak alınmıştır.

Tasarımda kullanılacak veriler elde edildikten sonra ANSYS yazılımı kullanılarak U şekilli betonarme perdenin sonlu eleman modeli yapılmıştır. Modelin oluşturulmasında 8-düğüm noktalı katı eleman SOLID65 kullanılmış, en az sayıda sonlu eleman oluşturacak şekilde düzenleme yapılarak çözüm süresinin kısaltılmasına dikkat edilmiştir. Şekil 4'de U şekilli perdenin boyutları ile sonlu eleman görüntüsü gösterilmiştir. Perde uç bölgelerinde perde kalınlığı, DBYBHY-07 [9] ye uygun olarak 200 mm olarak belirlenmiştir.
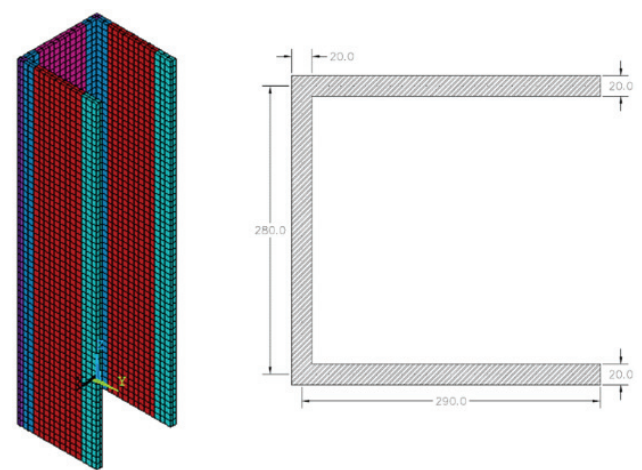

Şekil 4 - U Şekilli Perdenin Boyutları ve Sonlu Eleman Modeli 
DBYBHY-07 [9], sargılı veya sargısız beton gerilme-birim şekil değiştirme malzeme modelleri için Mander [10] vb. modelini önermiştir. Saatçioğlu ve Razvi [11] modeli, Mander [10] modeliyle tepe gerilmesi benzer eğriler vermekle birlikte, yumuşama bölgesinde daha gerçekçi bir davranış sergilemektedir [12]. Dolayısıyla hesaplarda sargılı betonun gerilme-birim şekil değiştirme eğrisi Saatçioğlu ve Razvi [11] modeliyle, sargısız betonun gerilme-birim şekil değiştirme eğrisi ise Geliştirilmiş Hognestad modeliyle hesaplanmıştır [13].

U şekilli betonarme perdenin sonlu eleman modelinde, kolların uç kısımları ve gövde-kol birleşim bölgelerinde sargılı beton modelleri, diğer kısımlarında ise sargısız beton modelleri kullanılmıştır. Sargılı ve sargısız betonun gerilme-birim şekil değiştirme eğrisi ile bunların modellemede kullanılan çok doğrulu halleri Şekil 5'de verilmiştir.

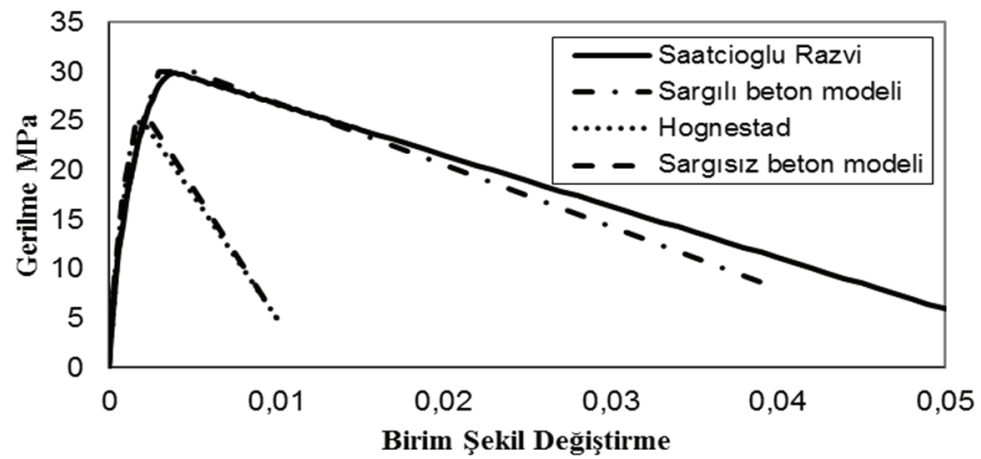

Şekil 5 - Sargıll ve Sargısız Beton Modelleri

U şekilli betonarme perdenin sonlu eleman ile modellenmesinde kullanılan beton malzemenin dayanım sınıfı C25/30 olarak belirlenmiş, betonun elastisite modülü ise 31000 MPa olarak alınmıştır. Donatı çeliği elastik modülü $200000 \mathrm{MPa}$, akma dayanımı $420 \mathrm{MPa}$ ve akma sonrası teğet modülü 550 olacak şekilde iki doğrulu model olarak alınmıştır (Şekil $6)$.

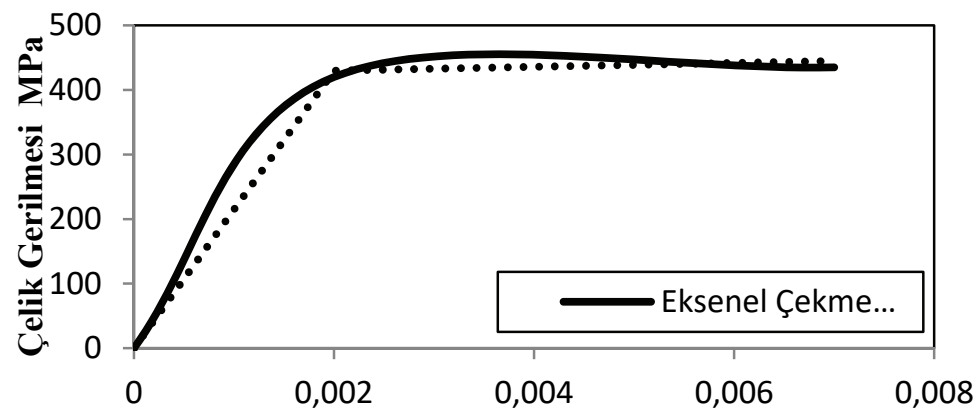

Birim Şekil Değiştirme

Şekil 6 - Çelik İ̧̧in Kullanılan Malzeme Modeli 


\subsection{Kullanılan Sonlu Eleman Modelleme Yönteminin Güvenilirliği}

U şekilli betonarme perdenin modellenmesinde kullanılan sonlu eleman modelleme yönteminin güvenilirliğinin gösterilmesi ve uyumluluğunun yapılması bu çalışma için oldukça büyük önem taşımaktadır. Bu bakımdan Maruta ve arkadaşlarının [5], aynı anda yatay yük ve burulmaya maruz bırakılan $H$ şekilli betonarme perde için yaptıkları deneysel çalışma verilerinden yola çıkarak, perdenin sonlu eleman modellemesi yapılmıştır. Deneysel veriler ile sonlu eleman analizlerinden elde edilen eğilme momenti-yanal ötelenme ilişkisi belirlenmiştir.

Maruta ve arkadaşları [5]' nın yaptıkları çalışmada HW25, HW75 ve HS25 olmak üzere 3 adet $\mathrm{H}$ şekilli betonarme perdeye ait olan donatı planı ile kesit geometrisi ve boyutları Şekil $7 a^{\prime} d a$, perdeye uygulanan eğilme ve burulma momentlerinin uygulanma yön ve doğrultuları ise Şekil 7b'de gösterilmiştir.

a)

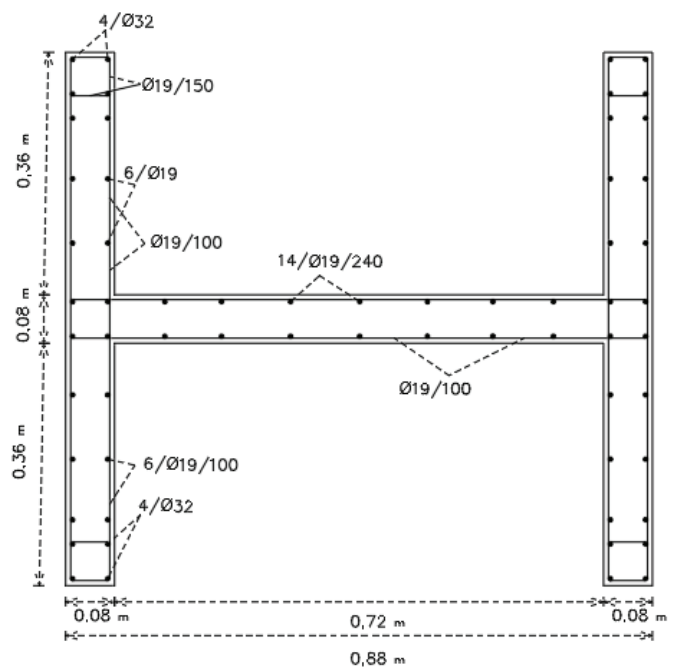

b)
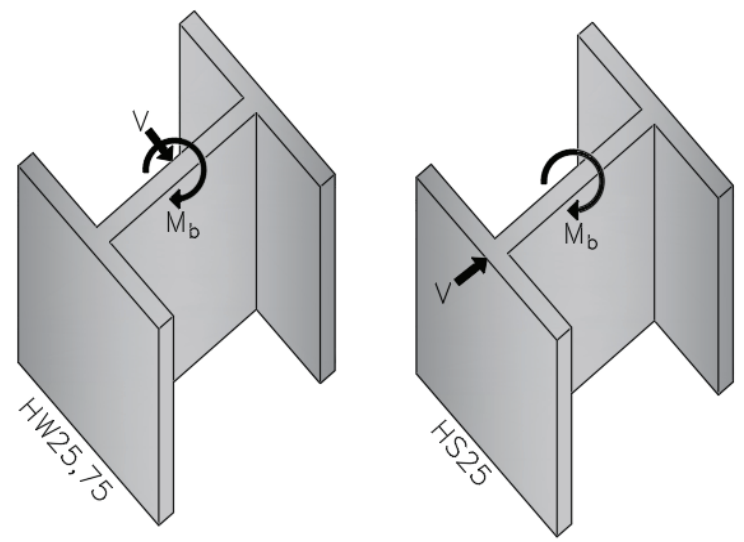

Şekil 7 - a) H Şekilli Perdenin Donatı Planı Ve Kesit Geometrisi[5] b) Eğilme Ve Burulma Momentlerinin Yön ve Doğrultularl 


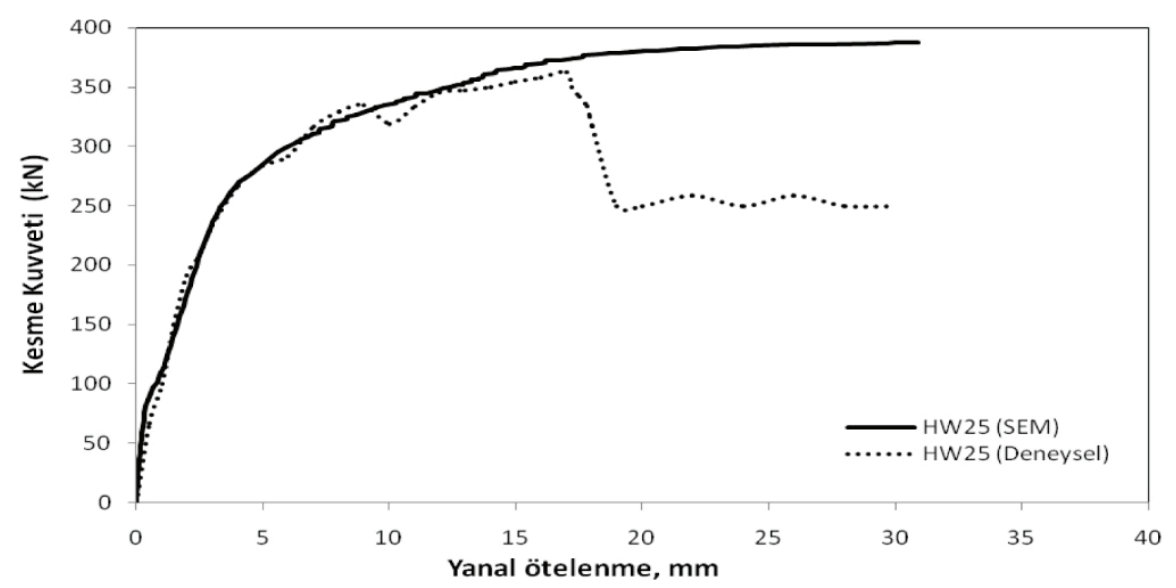

Şekil 8 - Kesme Kuvveti-Yanal Ötelenme İlişkisi (HW25)

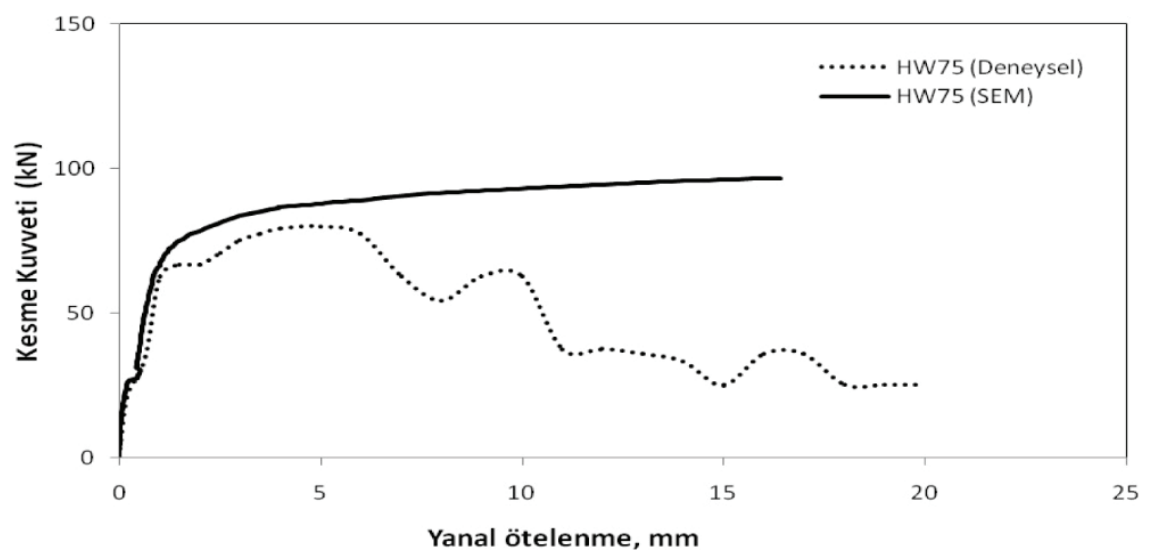

Şekil 9 - Kesme Kuvveti-Yanal Ötelenme İlişkisi (HW75)

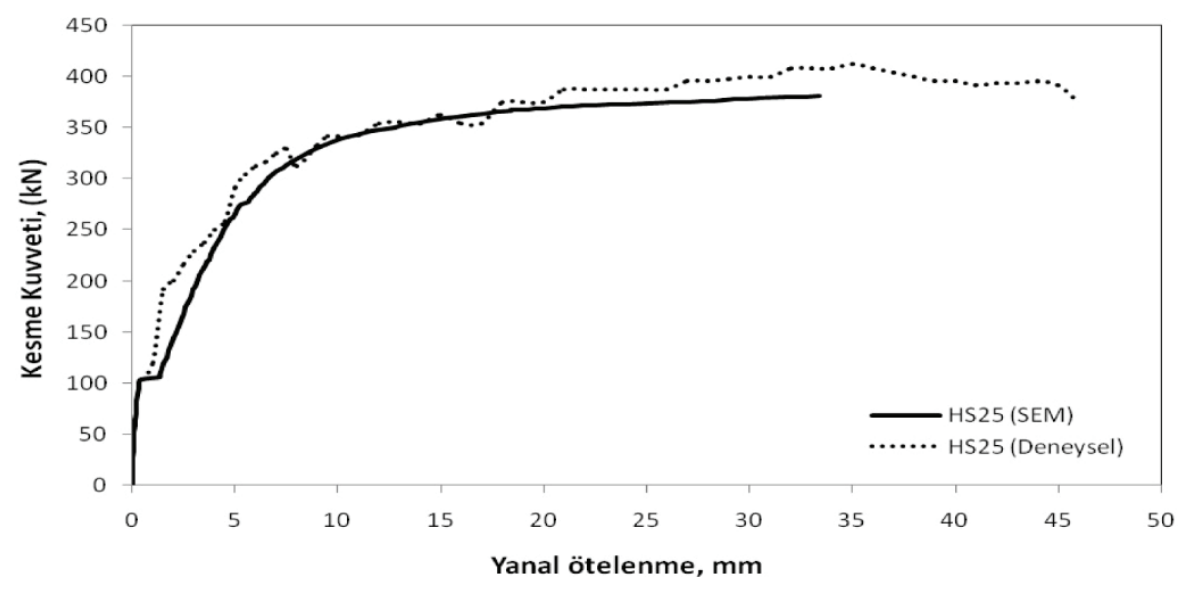

Şekil 10 - Kesme Kuvveti-Yanal Ötelenme Ilişskisi (HS25) 
Şekil 8, Şekil 9 ve Şekil 10'da görüldüğü gibi HW25, HW75 ve HS25 perdelerinin hepsinde ulaşılan kesme kuvveti kapasitesi, deneysel verilerden elde edilen kesme kuvveti kapasitesine çok yakın sonuçlar vermektedir. Bu nedenle sonlu eleman modelleme yönteminin güvenilir olduğu ve U şekilli betonarme perdenin doğrusal ötesi analizlerinde gerçeğe yakın sonuçlar vereceği düşünülmektedir.

\section{ARAŞTIRMA BULGULARI}

U şekilli betonarme perdenin en üst ucunda MPC184 uyum elemanının rijit kiriş özelliğinden faydalanılarak Şekil 11 b'de gösterilen şekilde perdenin gövdesine kesit ağırlık merkezi ve kesit kayma merkezinden uygulanan kesme kuvveti ve eksenel kuvvet etkileri altında yapılan doğrusal olmayan analizler neticesinde her bir model için kesme kuvveti-tepe noktası ötelenme eğrileri çizilmiştir. Şekil 11a'daki ötelenme eğrileri, perdenin en üst ucunda yükün uygulandığı nokta için hesaplanmıştır.
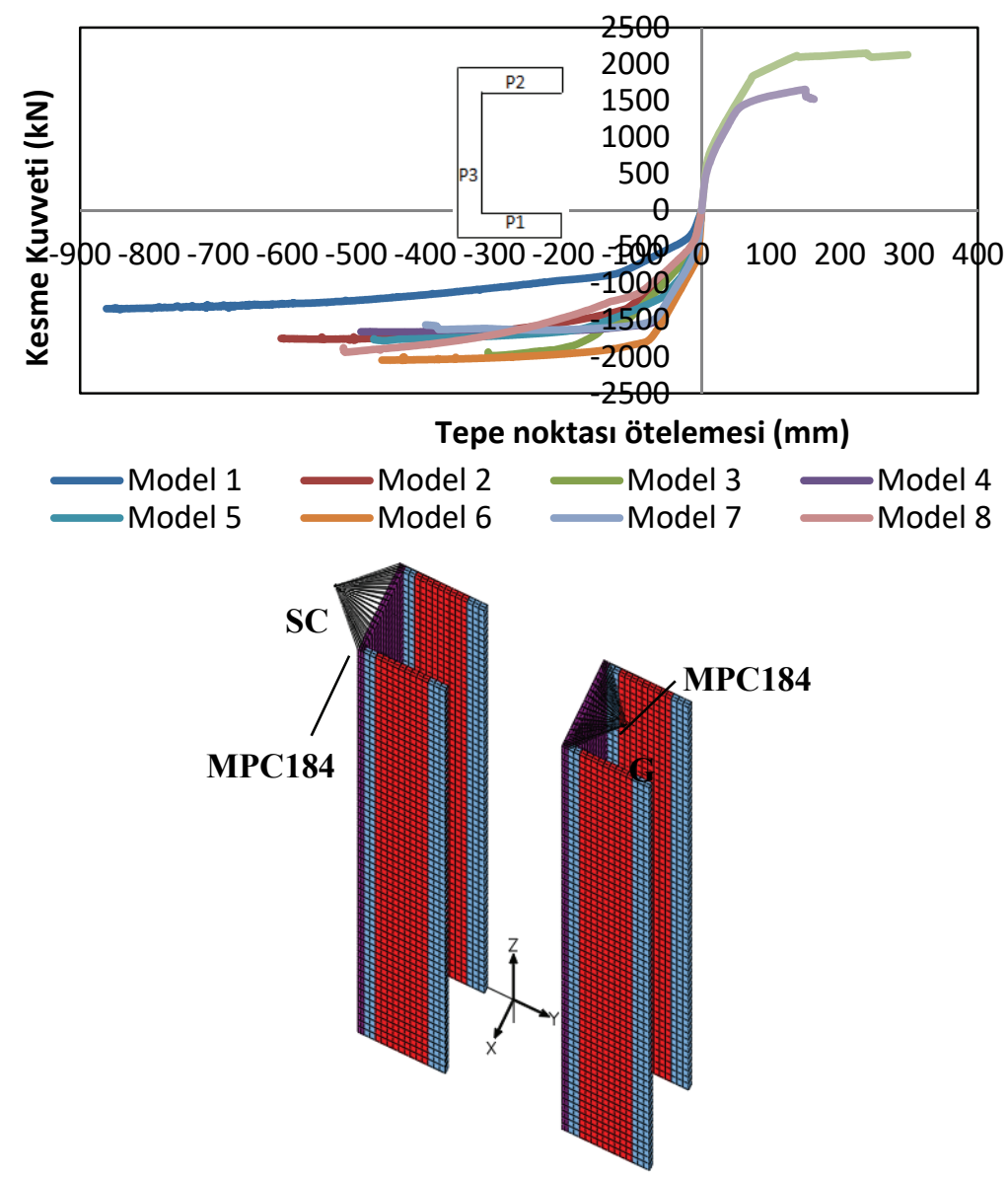

Şekil 11 - a) Model Yüklemelere Ait Kesme Kuvveti-Deformasyon Ĕ̆rileri b) Kesme Kuvvetinin Perdeye Uygulanma Düzeni 
Model 9 ve Model 10 yüklemelerinde uygulanan kesme kuvveti +y yönünde, Model 4 ve Model 5 yüklemelerinde $-\mathrm{y}$ yönünde, Model 1,2 ve 6 yüklemelerinde ise -x yönünde olmasından dolayı Şekil 11a'daki grafik elde edilmiştir. Model 1'de u şekilli betonarme perdenin en üst ucunda kesit ağırlık merkezine uygulanan kesme kuvveti, kesitte hem eğilme hem de burulma etkisi meydana getirmiştir. Yapılan doğrusal ötesi analiz sonucunda perdenin en alt kısmında P1 kolunun P3 gövdesi ile birleştiği bölgede birim şekil değiştirmenin 0,0041 değerine ulaştığı ve bu bölgede çekmeden dolayı donatıların aktığı belirlenmiştir. P2 kolunun P3 gövdesi ile birleştiği bölgede ise birim şekil değiştirmenin 0,0026 değerine ulaştı̆̆ı, basınç etkilerinin yoğun olduğu ve bölgedeki betonun ezilme sınırına yaklaştığı görülmektedir (Şekil 12).
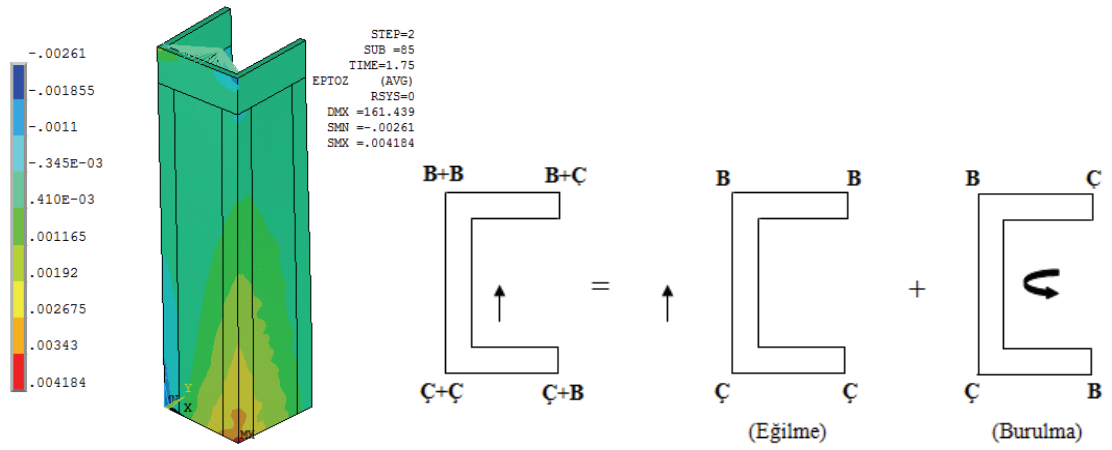

Şekil 12 - Yüklemeden Doğan Eğilme ve Burulma Etkileri (Model 1)

Model 2'de U şekilli betonarme perdenin en üst ucunda gövde kısmının tam ortasında bir noktadan uygulanan kesme kuvveti, kesitte çatlak oluşumu başlatmıştır. Perdenin en alt kısmında P1 kolunun P3 gövdesi ile birleştiği bölgede 0,0047 olan birim şekil değiştirme değeri çekme etkilerinin yoğun olduğunu göstermektedir. Bu bölgede donatılar akmıştır. P2 kolunun P3 gövdesi ile birleştiği bölgede ise basınç etkileri oluşmuş, birim şekil değiştirme değeri 0,0031 e ulaşarak betonun ezilme anına yaklaştığı görülmektedir. Kesitte oluşan burulma momentinin yönüne bağlı olarak P1 ve P2 kollarındaki basınç ve çekme bölgeleri değişim göstermektedir (Şekil 13).
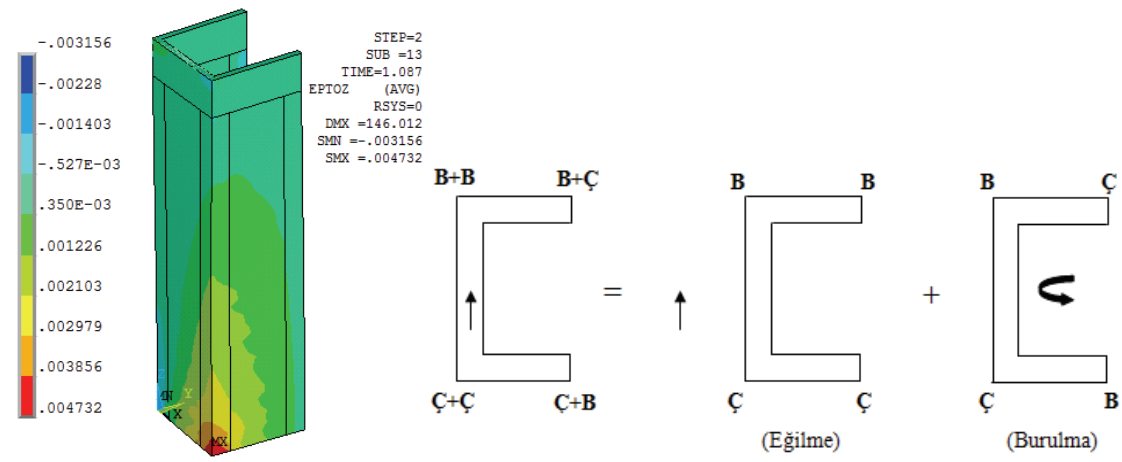

Şekil 13 - Yüklemeden Doğan Eğilme ve Burulma Etkileri (Model 2) 
Model 6'da U şekilli betonarme perde, perdenin en üst ucunda, kesit kayma merkezinden -x yönünde kesme kuvveti etkisine maruz bırakılmıştır. Birim şekil değiştirme değeri perdenin en alt kısmında P1 kolunun P3 gövdesi ile birleştiği bölgede 0,0047 ye ulaşarak donatılar akmıştır. Bu bölgede çekme etkileri ön plana çımıştır. Perdenin P2 kolunun P3 gövdesi ile birleştiği bölgede ise birim şekil değiştirme değerinin 0,0028 olduğu görülmektedir. $\mathrm{Bu}$ bölgede basınç etkileri yoğun olarak görülmekte, beton ezilme sınırına henüz ulaşmamıştır. Model 6'da kesme kuvveti perdenin kayma merkezinden uygulanmış olması burulma etkisinin oluşmamasını sağlamıştır. Burulma etkisinin olmaması çekme ve basınç bölgelerinin daha düzenli dağıldığını göstermektedir. Kesitte sadece düz eğilme etkisi vardır (Şekil 14).
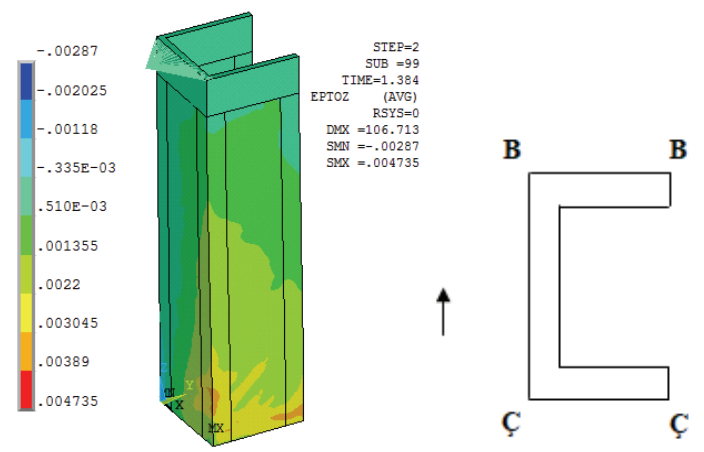

Şekil 14 - Yüklemeden Doğan Eğilme ve Burulma Etkileri (Model 6)

Model 4 ve Model 9'daki yüklemeler perdenin en üst ucunda tersinir olacak şekilde yapılmıştır. Model 4'de uygulanan kesme kuvveti -y yönünde etki etmekte ve perdenin en alt kısmında birim şekil değiştirmenin 0,0051 değerine ulaştığ görülmektedir. P1 ve P2 kollarının uç kısımlarında çekme etkilerinin yoğun olduğu ve donatıların aktığı görülmektedir. Model 9'da ise kesme kuvveti y yönünde etki etmekte ve kol uçlarında basınç, gövde bölgesinde ise çekme etkileri oluşmaktadır. Birim şekil değiştirme perdenin P1 ve P2 kolu uç bölgesinde 0,0096 'ya ulaştığı ve betonun ezildiği belirlenmiştir. (Şekil 15).
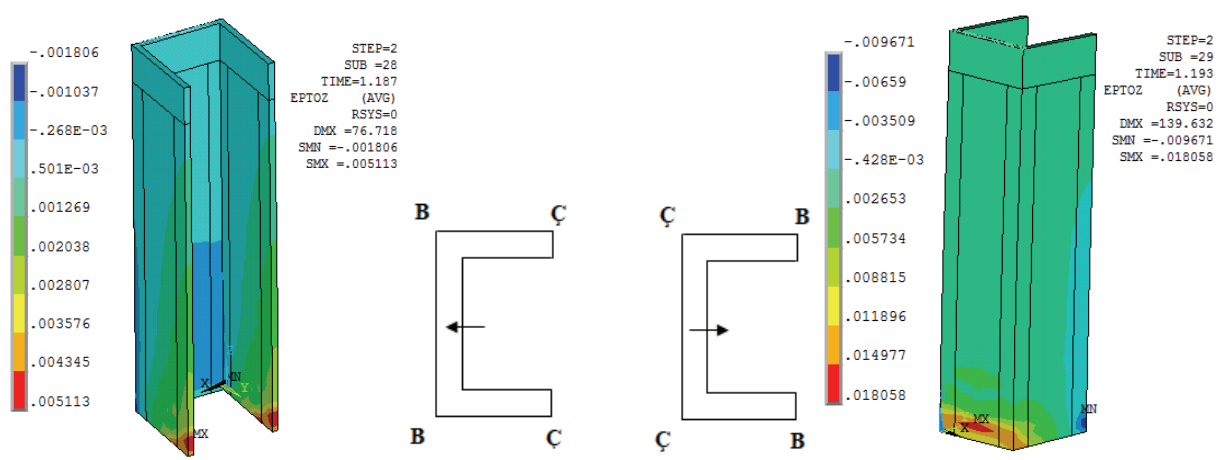

Şekil 15 - Yüklemeden Doğan Ĕ̆ilme ve Burulma Etkileri (Model 4 ve Model 9) 
Model 5 ve Model 10'daki yüklemeler perdenin en üst ucunda tersinir olacak şekilde yapılmış ve kesitte burulma etkisi oluşması için kesme kuvveti perdenin ağırlık merkezinden $-\mathrm{x}$ yönünde $1 \mathrm{~m}$ çekilerek uygulanmıştır. Model 5 'de $\mathrm{U}$ şekilli betonarme perdede -y yönündeki kesme kuvveti etkisinde perdenin en altında P2 kolunun uç kısmında yoğun olmak üzere çekme etkileri oluşmaktadır. Burada birim şekil değiştirmenin 0,01 ile donatının akma sınırını aştığı görülmektedir. Model 10'da kesme kuvvetinin y yönünde uygulanması halinde perdenin en alt kısmında P2 kolu ile P3 gövde birleşim bölgesinde çekme etkileri oluşmakta, burulma momentinin etkisi ile çekme etkisi daha da artmaktadır (Şekil 16).
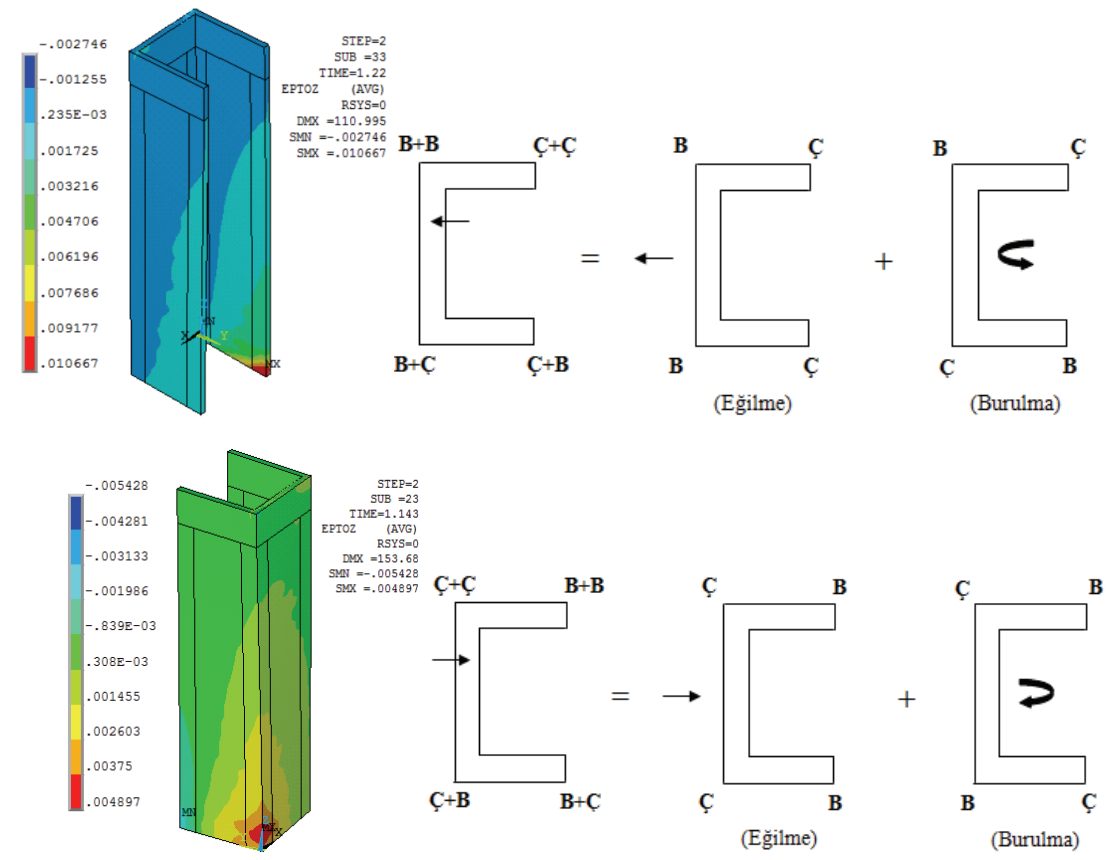

Şekil 16 - Yüklemeden Doğan Ĕgilme ve Burulma Etkileri (Model 5 ve Model 10)

Model 3'de perde kesitinde hem eğik eğilme durumu hem de burulma etkisi söz konusudur. Perdenin en alt kısmında P1 ve P2 kolu uç bölgesinde yoğun olmak üzere çekme etkileri oluşurken, birim şekil değiştirmenin 0,0016 olduğu belirlenmiştir. $\mathrm{Bu}$ anda uç bölge donatılarının akmadığı anlaşılmaktadır. (Şekil 17).

Model 8'in Model 3'den tek farkı y doğrultusunda uygulanan yükün yönüdür. U şekilli perdenin en üst ucundan $-\mathrm{x}$ yönündeki kesme kuvveti etkisi altında perdenin en alt kısmında P1 kolu ile P3 gövdesinin birleştiği bölgede çekme etkileri oluşmakta, birim şekil değiş̧irmenin 0,004 değerine ulaşması ile donatının aktı̆̆ı belirlenmiştir. P2 kolu ile P2 kolunun P3 gövdesi birleşim bölgesinde basınç etkileri ön plandadır. Burada birim şekil değiştirme değeri 0,0021 olması betonun çatladığı ancak henüz ezilme sınırına ulaşmadığını göstermektedir (Şekil 18). 


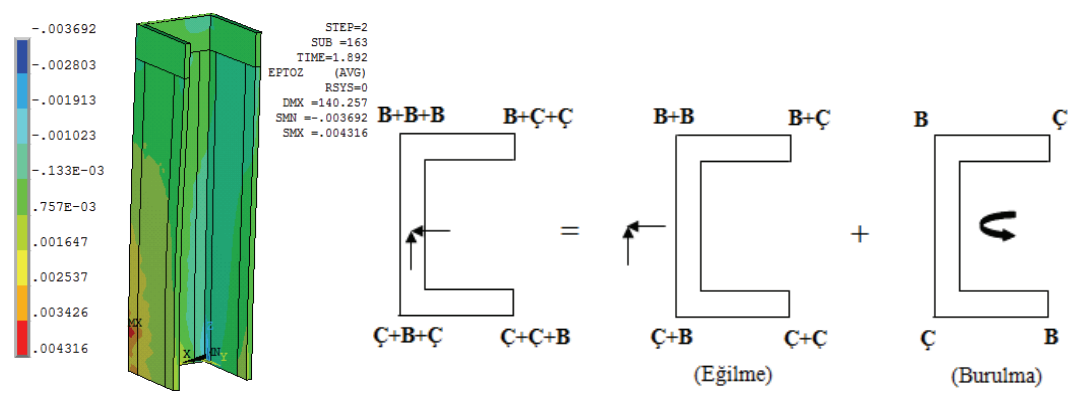

Şekil 17 - Yüklemeden Doğan Eğilme ve Burulma Etkileri (Model 3)
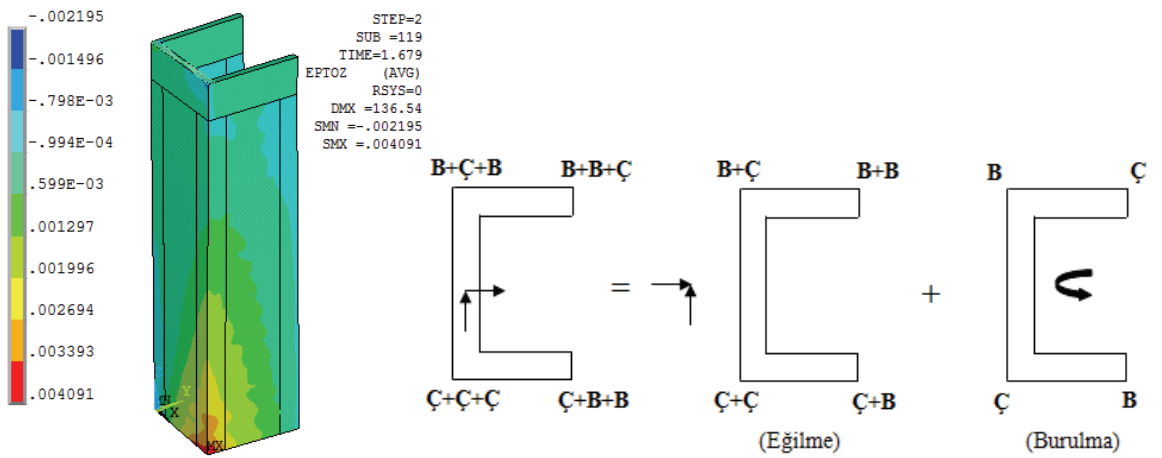

Şekil 18 - Yüklemeden Doğan Ĕ̈ilme ve Burulma Etkileri (Model 8)

Model 7'de u şekilli betonarme perdenin en üst ucundan $+x$ yönündeki kesme kuvveti etkisi altında P2 kolunda çekme etkisi oluşurken, P1 kolunun gövde ile birleştiği bölgede basınç etkisi meydana gelmektedir. -y yönündeki kesme kuvveti perdenin kol uçlarında çekme etkisi oluştururken, birim şekil değiştirmenin 0,0042 olması donatının aktığını göstermektedir (Şekil 19).
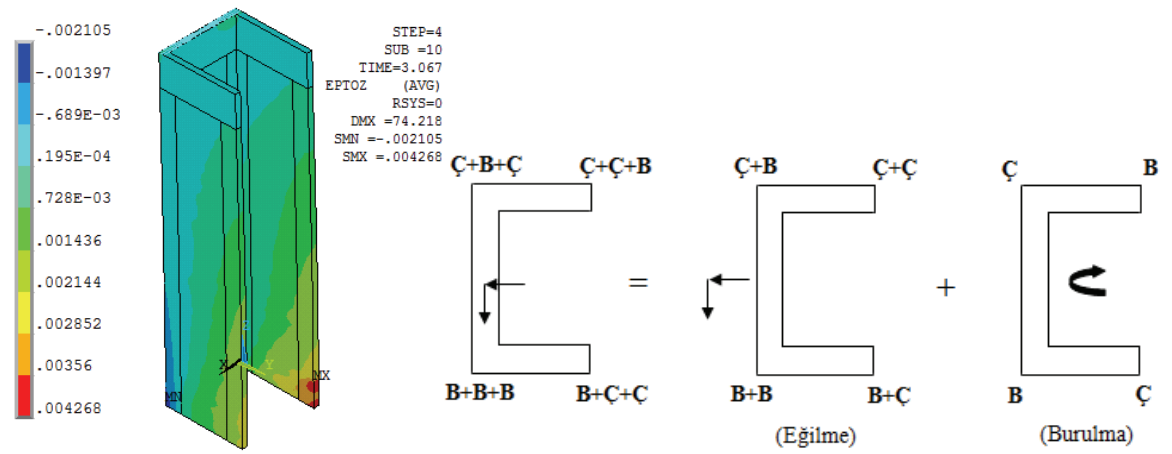

Şekil 19 - Yüklemeden Doğan Eğilme ve Burulma Etkileri (Model 7) 
U şekilli betonarme perdelerin ANSYS'de yapılan doğrusal ötesi analizleri sonucunda perdede meydana gelen deformasyon şekillerini açıklaması bakımından her bir modelin perde en alt noktasından itibaren $200 \mathrm{~mm}$ yüksekliğindeki bölge üzerinde ölçülen ve hesaplanan birim şekil değiştirme dağılımları, $\% 1$ ve $\% 2$ ötelenme oranları için belirlenmiştir.

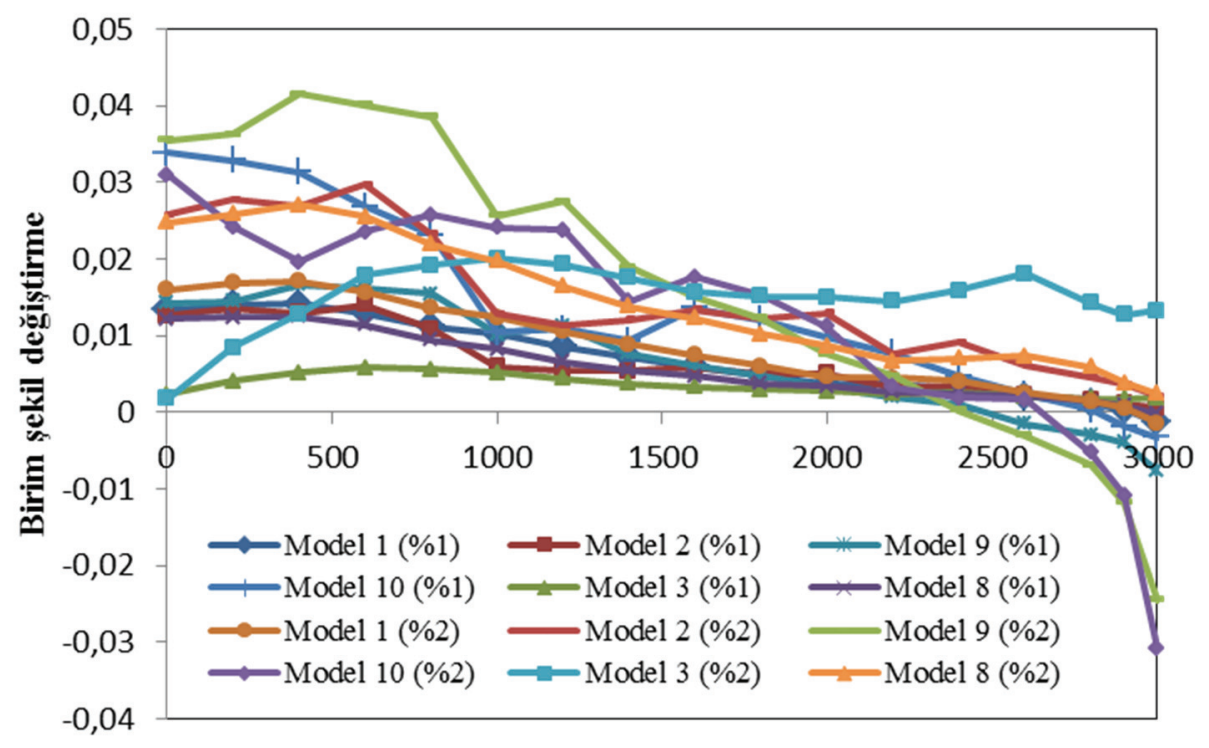

Gövde ekseni (mm)

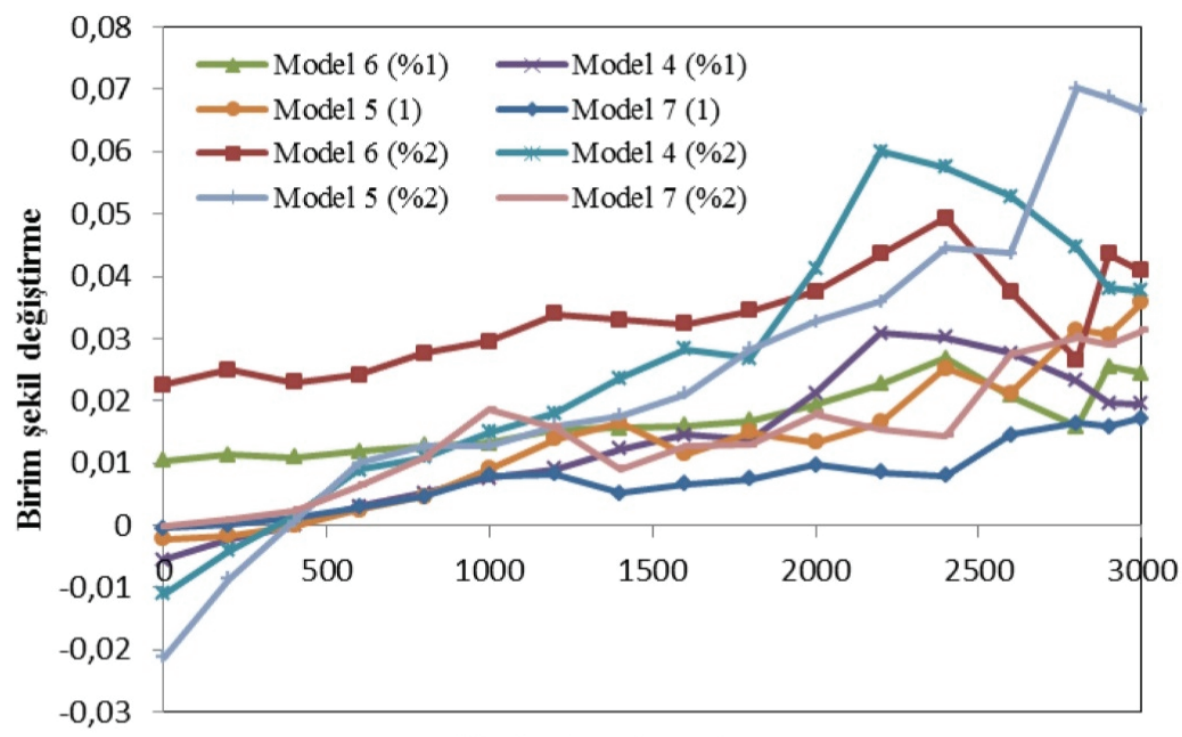

Gövde ekseni (mm)

Şekil 20 - Birim Şekil Değiştirme Dă̆llımları (\%1 ve \%2 Ötelenme Oranında) 
U şekilli betonarme perdenin en üst kısmında Şekil 21'de gösterilen 1, 2, 3 ve 4 nolu düğüm noktalarında belirlenen ortalama ötelenmeler ile burulmada dönme açıları, $\omega^{\circ}$ (ötelenmeler perdenin en alt kısmından itibaren $200 \mathrm{~mm}$ yüksekliğindeki P3 gövde bölgesinde birim şekil değiştirmenin 0,0038 değerine ulaştığ 1 anda hesaplanmıştır) Tablo 1'de gösterilmektedir.
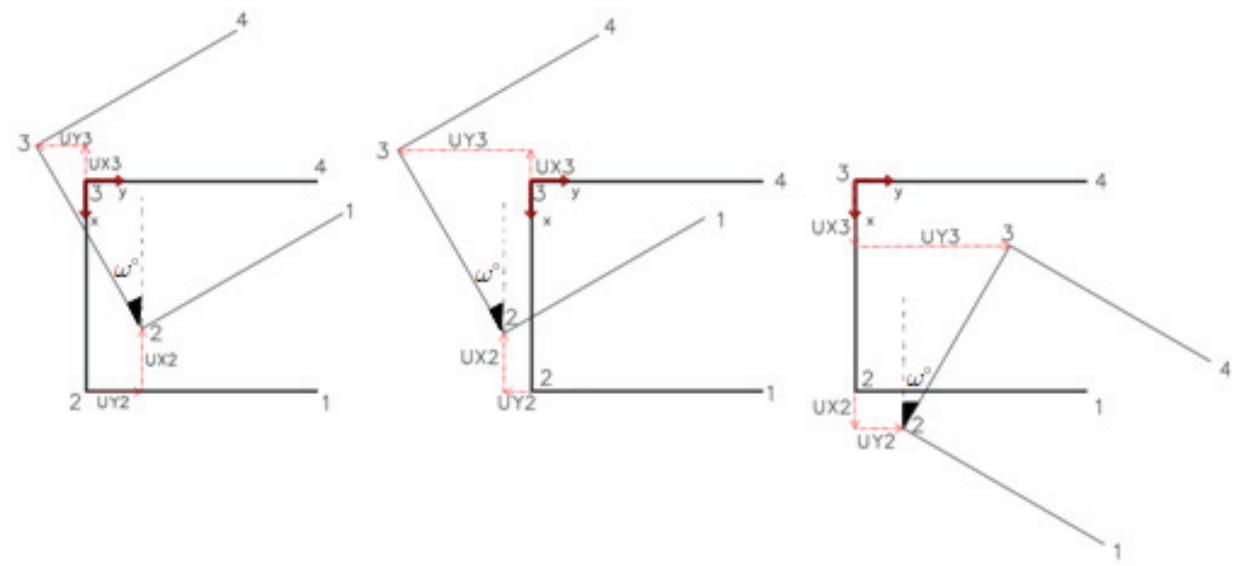

Şekil 21 - Ortalama Ötelenmelerin Doğrultuları ve Burulmada Dönme Açısı

Tablo 1 - Burulmada Dönme Açıları ve Ortalama Ötelenmeler

\begin{tabular}{|c|c|c|c|c|}
\hline \multirow{2}{*}{ Model Adı } & Burulma Dönme & \multicolumn{3}{|c|}{ Ortalama Ötelenme (mm) } \\
\cline { 3 - 5 } & Açısı $\left(\omega^{\circ}\right)$ & UX & UY & UZ \\
\hline Model 1 & 1,613 & $-109,60$ & 16,89 & 0,97 \\
\hline Model 2 & 1,210 & $-111,76$ & 17,91 & 1,77 \\
\hline Model 6 & 0,55 & $-80,27$ & $-5,34$ & 6,06 \\
\hline Model 4 & 0 & 0,00 & $-74,77$ & 6,37 \\
\hline Model 9 & 0 & 0,00 & 141,66 & 4,60 \\
\hline Model 5 & 1,253 & $-33,22$ & $-55,77$ & 4,23 \\
\hline Model 10 & 1,600 & 79,69 & 60,88 & 0,57 \\
\hline Model 3 & 1,015 & $-116,27$ & $-3,50$ & 3,28 \\
\hline Model 8 & 1,161 & $-99,77$ & 27,47 & 1,30 \\
\hline Model 7 & 0,268 & 64,88 & $-244,10$ & 23,57 \\
\hline
\end{tabular}

\subsection{Sonlu Eleman Modelinde Eğriliğin Tanımı}

Eğilme ve eksenel kuvvet ya da yalnız eğilme etkisi altındaki bir kesitin davranışını belirlemek için gerçek malzeme davranışını temel alarak modellenmiş bir elemanın momenteğrilik ilişkisi elde edilebilir. 
Moment-eğrilik ilişkisini oluşturan $M_{i}$ ve $K_{i}$ değerlerini iterasyon metoduyla hesaplayabilmek için denge ve uygunluk denklemlerinden faydalanılır.

Bir kiriş kesitinden faydalanılacak olursa, $c$ (tarafsız eksen derinliği) değeri için varsayımlar yapılır, $c$ değeri kuvvetler dengesi sağlanıncaya kadar değiştirilir. En dış lifteki beton birim kısalması, $\varepsilon_{c i}$ için bir değer seçilir. Bilinen $\varepsilon_{c i}$ ve c için çelik birim deformasyonları, $\varepsilon_{s i}$ bulunur. Bulunan $\varepsilon_{s i}$ değerlerinden donatıdaki gerilmeler ve donatı kuvvetleri tespit edilir. Beton basınç bileşkesi $F_{c}$ hesaplanır. Dengeye ulaşıldıktan sonra, iç kuvvetlerin ağırlık merkezi etrafındaki momenti hesaplanarak $M_{i}$ bulunur. Eğrilik ise Denklem (1) de belirtilen şekilde belirlenir.

$K_{i}=\frac{\varepsilon_{c i}}{c}$

U şekilli betonarme perdenin Şekil 22'de gösterilen sonlu eleman modelinde perde tabanında her bir yatay sıra katı eleman için hesaplanan eğrilik, P3 gövdesi boyunca gövde uç noktalarında 12 ve 28 nolu düğüm noktaları için belirlenen birim şekil değiştirme değerleri kullanılarak Denklem (2)'de gösterildiği gibi hesaplanmıştır.

$\phi=\left(\left|\varepsilon_{28}\right|+\left|\varepsilon_{12}\right|\right) / \mathrm{L}$

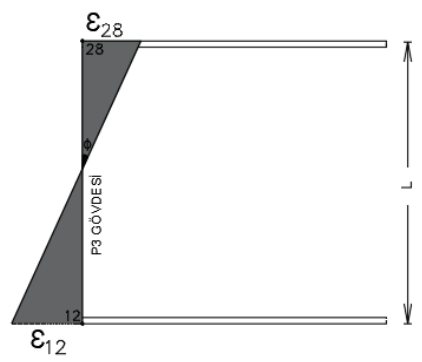

Şekil 22 - Sonlu Eleman Modelinde Ĕgriliğin Tanımlanması

Şekil 23, Şekil 24, Şekil 25, Şekil 26 ve Şekil 27' de model analizlere ait moment-eğrilik ilişkileri verilmiştir. Modellerin tümünde eksenel kuvvet $(\mathrm{N}=5400 \mathrm{kN})$ olarak $-\mathrm{z}$ yönünde alınmıştır. Sonlu eleman analizinden elde edilen moment-eğrilik grafikleri (SEM), burulma etkisinin olmadığı modeller için kesit analizinden elde edilen moment-eğrilik grafikleri (KH) ile karşılaştırılmıştır. Burulma momenti sonucu kesitte meydana gelen çarpılma etkisinden dolayı "şekil değiştirmeden önce düzlem olan kesitin şekil değiştirmeden sonra düzlem kalması" hipotezi geçerliliğini kaybetmektedir. Bu sebepten dolayı düzlem kesit hipotezi kullanarak burulma momentinin olduğu modellerde eğrilik elde etmek kesit çarpılmasından dolayı uygun olmamaktadır. Sonlu eleman analizinden elde edilen değerlerin, kesit analizi ile elde edilenden farklı olması beklenen bir sonuçtur. Çünkü sonlu eleman modellemesinde 
kullanılan Solid65 betonarme elemanı çatlama özelliğine sahiptir ve kesitin çatlama davranışından dolayı, taşıyabileceği maksimum moment değeri daha düşük olmaktadır.

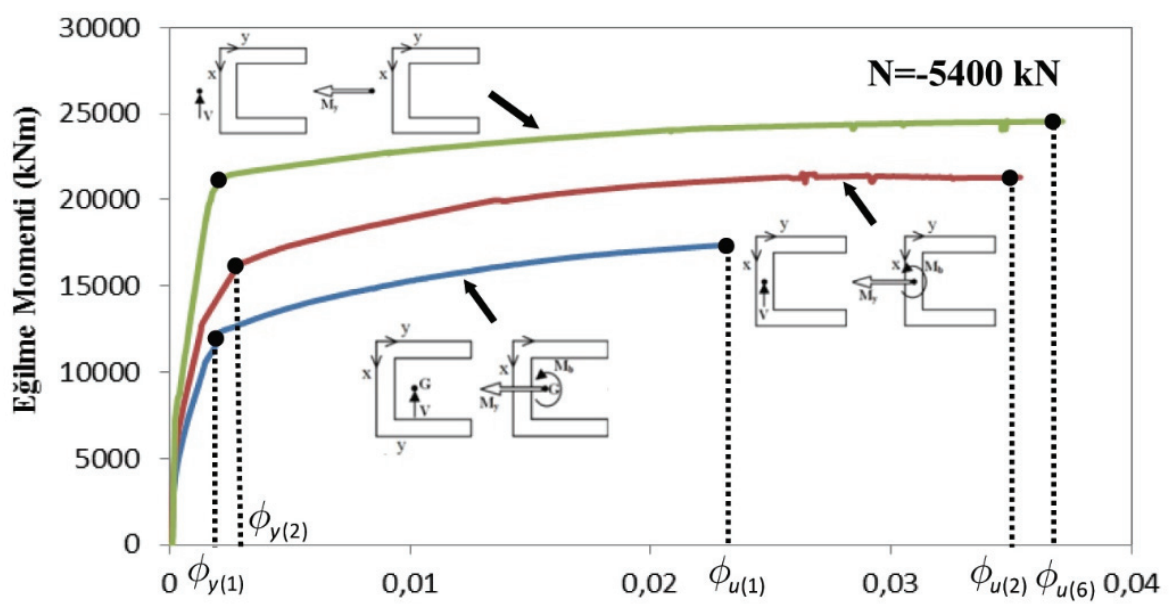

Ĕgrilik (1/m)

Model 1 SEM $\longrightarrow$ Model 2 SEM $\longrightarrow$ Model 6 SEM

Şekil 23 - Model Analizlere Ait Moment-Ĕ̆rilik İlişkileri

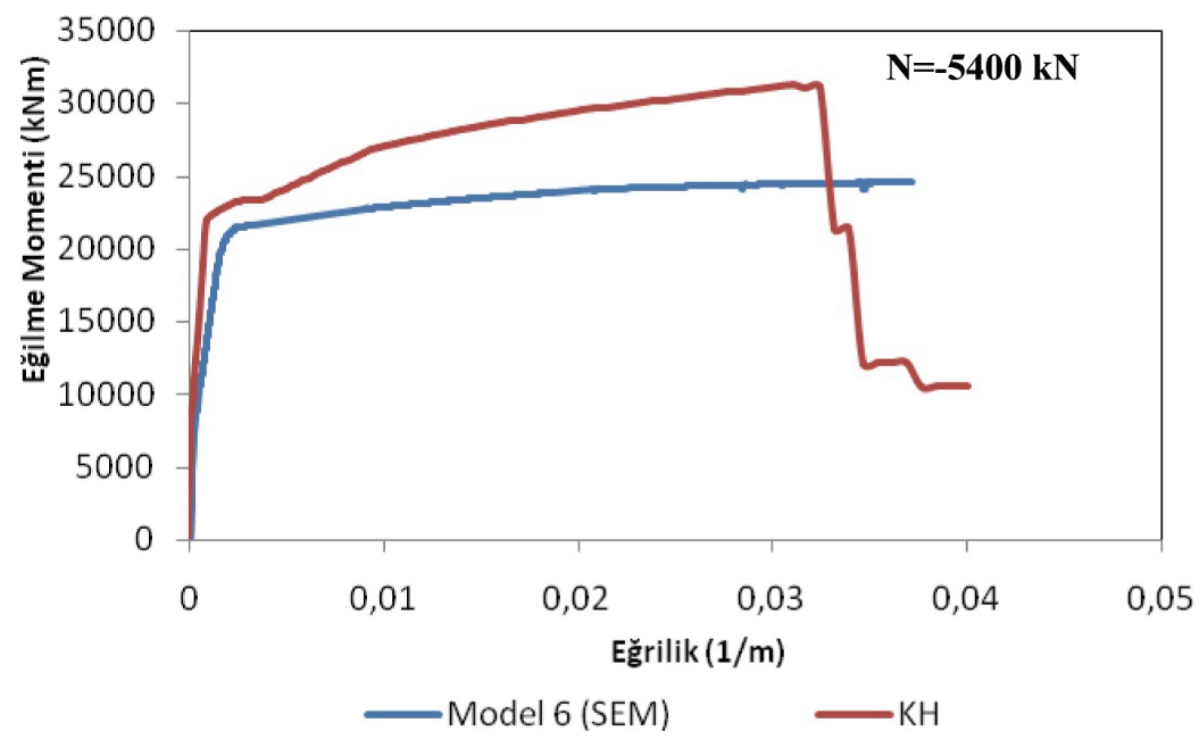

Şekil 24: Model analizlere ait moment-eğrilik ilişkileri 


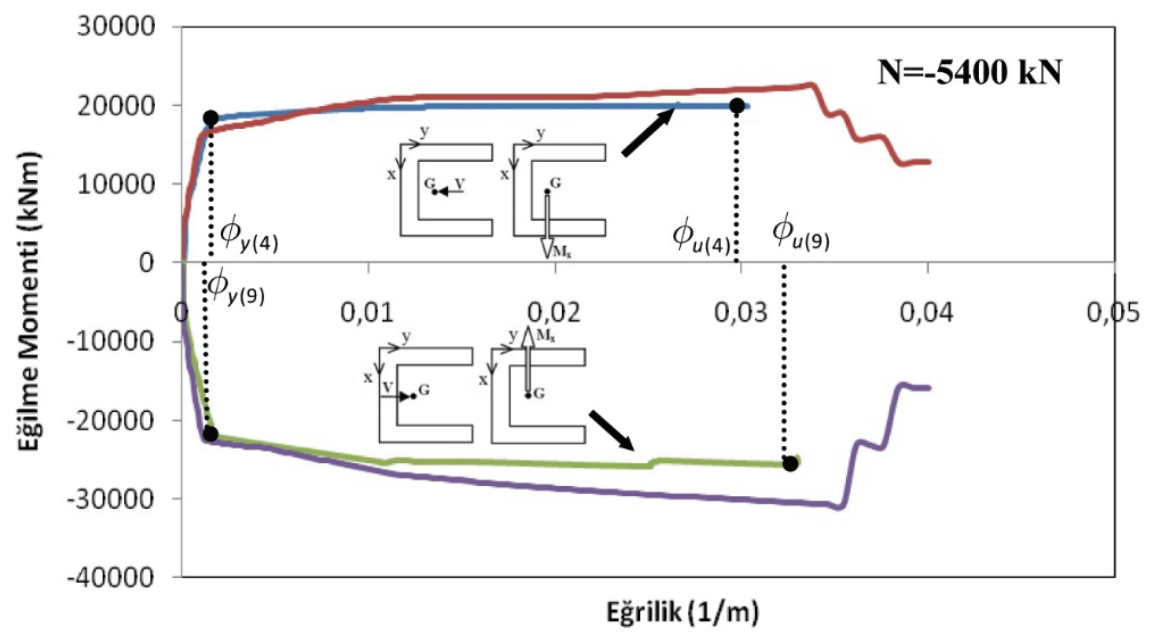

-Model 4 (SEM) —KH (Model 4 için) - Model 9 (SEM) —KH (Model 9 için) Şekil 25: Model analizlere ait moment-eğrilik ilişskileri

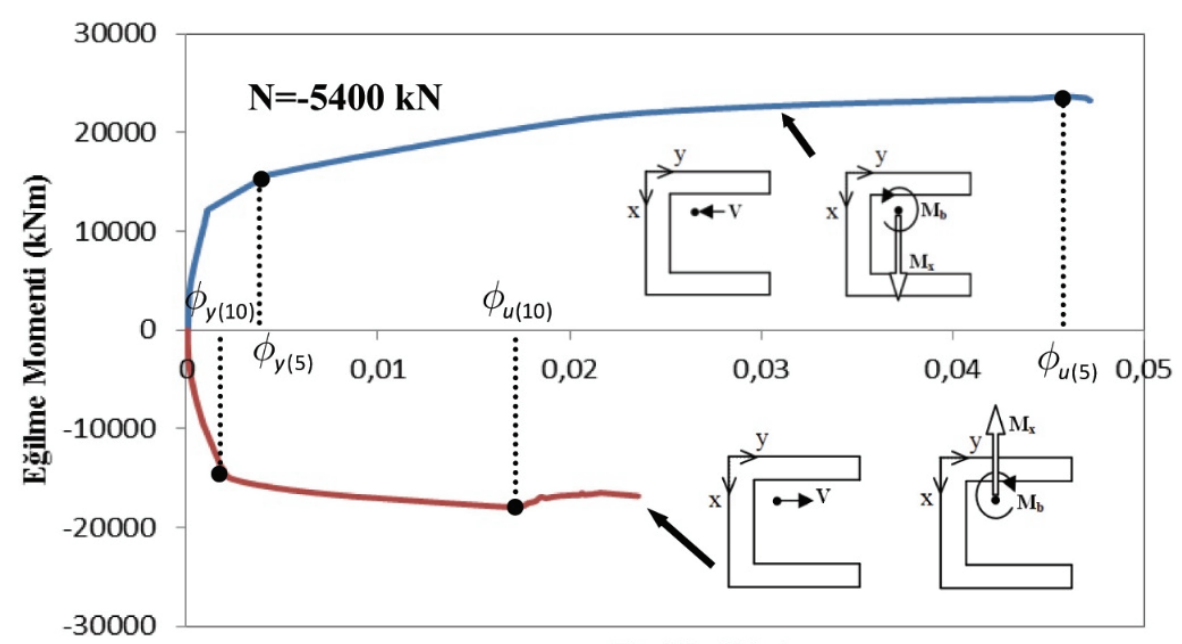

Ĕgrilik (1/m)

Model 5 SEM $\longrightarrow$ Model 10 SEM

Şekil 26: Model analizlere ait moment-eğrilik ilişskileri 


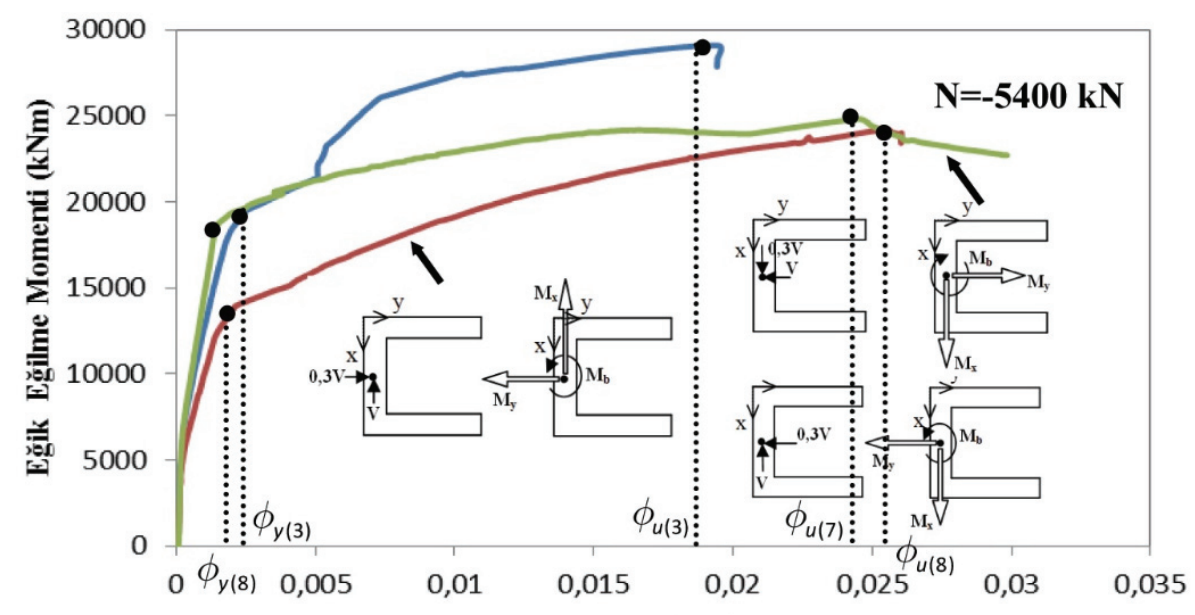

Eğrilik (1/m)

-Model 3 SEM $\longrightarrow$ Model 8 SEM $\longrightarrow$ Model 7 SEM

Şekil 27: Model analizlere ait moment-eğrilik ilişkileri

U şekilli betonarme perdenin doğrusal ötesi analizleri neticesinde sonlu eleman analizi ve kesit analizinden elde edilen eğrilik değerleri burulmanın olmadığg modeller için Tablo 2'de gösterilmiştir.

Tablo 2 - Perdelerde Ĕ̆rilik Değerlerinin Karşılaştırılması

\begin{tabular}{|c|c|c|c|}
\hline & SEM & KH & \multirow{2}{*}{ Model Adı } \\
\hline \multirow{2}{*}{$\boldsymbol{\varepsilon}$} & \multicolumn{2}{|c|}{$\boldsymbol{\varepsilon}_{\boldsymbol{c}}=\mathbf{0 , 0 4 6}$} & Model 4 \\
\hline \multirow{3}{*}{$\begin{array}{c}\text { Eğrilik } \\
(1 / \mathrm{m})\end{array}$} & 0,030 & 0,033 & Model 6 \\
\cline { 2 - 4 } & 0,035 & 0,037 & Model 9 \\
\hline
\end{tabular}

Eğilme etkisindeki bir kesitte, kesitin dayanımında önemli bir azalma meydana gelmeden oluşan en büyük eğriliğin $\left(\phi_{u}\right)$, doğrusal davranışa yakın davranışın bitimi sayılan çekme donatısında akmanın meydana geldiğindeki eğriliğe $\left(\phi_{y}\right)$ oranı, eğilme sünekliği olarak tanımlanır. Eğilme sünekliği Denklem (3)'de gösterilen şekilde hesaplanır [1].

$\mu=\phi_{u} / \phi_{y}$ 
Sonlu eleman modeli yapılan $U$ şekilli betonarme perdenin doğrusal ötesi analizleri neticesinde hesaplanan ve çizilen moment-eğrilik ilişkisi incelenerek her bir model için belirlenen eğilme sünekliği Tablo 3'de verilmiştir.

Tablo 3 - SEM Iç̧in Eğilme Sünekliğinin Karşılaştırılması

\begin{tabular}{|c|c|c|c|}
\hline Model Adı & $\phi_{y}$ & $\phi_{u}$ & $\mu=\phi_{u} / \phi_{y}$ \\
\hline Model 1 & 0,0021 & 0,023 & 10,9 \\
\hline Model 2 & 0,0028 & 0,035 & 12,5 \\
\hline Model 6 & 0,0023 & 0,037 & 16,1 \\
\hline Model 4 & 0,0015 & 0,030 & 20 \\
\hline Model 9 & 0,0016 & 0,033 & 20,6 \\
\hline Model 5 & 0,0043 & 0,045 & 10,5 \\
\hline Model 10 & 0,0022 & 0,017 & 7,7 \\
\hline Model 3 & 0,0022 & 0,019 & 8,6 \\
\hline Model 8 & 0,0019 & 0,026 & 13,7 \\
\hline Model 7 & 0,0017 & 0,024 & 14,1 \\
\hline
\end{tabular}

U şekilli betonarme perdenin verilen yükleme şekillerine göre yapılan doğrusal ötesi analizleri sonucunda perdenin kol ve gövde kısımlarının aldıkları kesme kuvvetleri ve bu kuvvetlerin pozitif yönleri Şekil 28'de gösterilmiştir (Tablo 4).

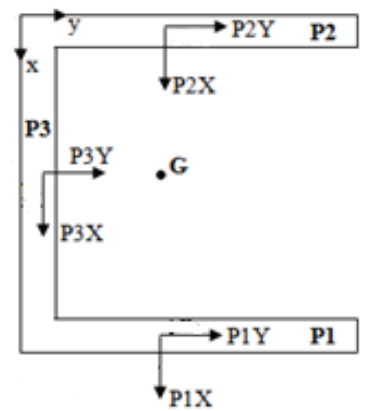

Şekil 28 - Kesme Kuvvetleri ve Yerlerinin Gösterilmesi

Deprem bölgelerinde gerek yapının güvenliğini sağlamak gerekse yer değiştirmeleri sınırlandırarak yapısal olmayan elemanlarda meydana gelecek hasarları azaltmak için perde elemanlara etkiyen yatay yüklerin perdenin kayma merkezlerinden uygulanması burulma etkisini ortadan kaldırması bakımından önemlidir. Bu açıdan $\mathrm{U}$ şekilli betonarme perdenin teorik olarak hesaplanan kayma merkezi ile farklı yatay yük ve burulma etkisi altında yapılan 
doğrusal ötesi analizler sonucunda hesaplanan kayma merkezi farklı ötelenme oranları için karşılaştırılmış (Tablo 5) ve Şekil 30'de gösterilmiştir.

Tablo 4 - SEM Için Perde Kol ve Gövdesindeki Toplam Kesme Kuvvetleri

\begin{tabular}{|c|c|c|c|c|c|c|c|c|c|}
\hline \multicolumn{3}{|c|}{$\sum V_{x}(\mathrm{kN})$} & \multicolumn{3}{|c|}{$\sum V_{y}(\mathrm{kN})$} & \multicolumn{3}{|c|}{$\sum V_{z}(\mathrm{kN})$} & \multirow{2}{*}{$\vdots$} \\
\hline P1 & P2 & P3 & P1 & P2 & P3 & P1 & P2 & P3 & \\
\hline 2,01 & 46,85 & 1277,20 & $-262,3$ & 23,54 & 238,74 & -1297 & 5886,31 & 810,67 & M1 \\
\hline 100,32 & 107,50 & 1550,35 & $-108,26$ & $-37,99$ & 146,49 & $-2871,2$ & 8618,02 & $-386,73$ & M2 \\
\hline$-84,76$ & 54,97 & 2064,43 & 484,39 & $-937,37$ & 452,98 & $-4658,2$ & 9474,16 & 584,02 & M6 \\
\hline$-33,97$ & 33,97 & 0,0 & 670,54 & 670,54 & 322,44 & $-4295,8$ & $-4295,85$ & 13952,84 & M4 \\
\hline$-12,63$ & 12,63 & 0,0 & $-1067,3$ & $-1067,3$ & 7,20 & 5138,44 & 5138,44 & $-4916,89$ & M9 \\
\hline 51,92 & 147,8 & $-199,76$ & 253,95 & 1206,04 & 294,23 & $-4250,6$ & $-4870,33$ & 14482,06 & M5 \\
\hline$-18,86$ & 92,92 & $-74,06$ & $-231,50$ & $-1405,4$ & 23,75 & 4427,22 & 4825,72 & $-3891,78$ & M10 \\
\hline$-20,18$ & 276,7 & 1709,94 & 361,16 & 259,33 & 452,48 & -4283 & 5431,83 & 4212,41 & M3 \\
\hline 51,0 & 147,7 & 1687,4 & 19,18 & 43,60 & 176,5 & -3389 & 8124,6 & 620,02 & M8 \\
\hline 591,29 & 734,52 & 239,93 & 591,29 & 734,52 & 239,93 & $-1168,9$ & $-4552,44$ & 11082,5 & M7 \\
\hline
\end{tabular}

U şekilli betonarme perdenin kayma merkezi (SC)' nin teorik olarak hesabı Denklem (4)' e göre hesaplanmıştır [14] (Şekil 29).

$$
e=\frac{b^{2} \cdot h^{2} \cdot t_{1}}{4 \cdot I_{x}}
$$

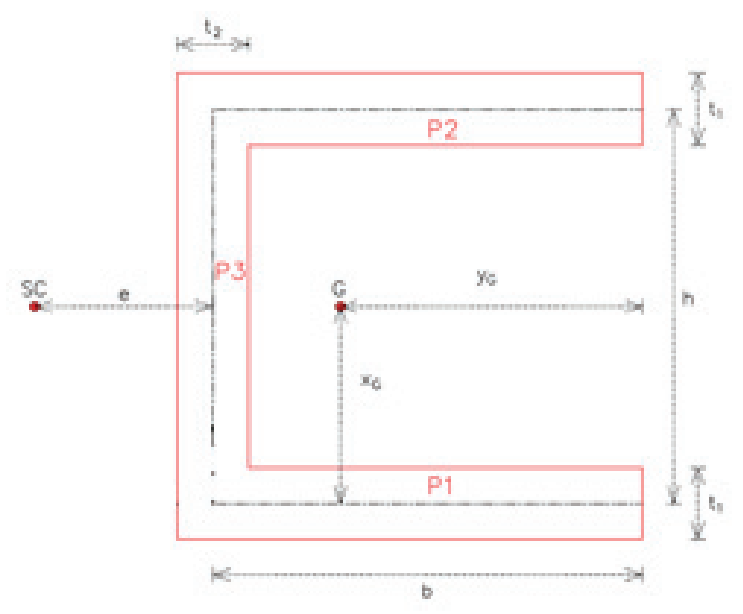

Şekil 29 - U Şekilli Betonarme Perde ve Kayma Merkezi 
Tablo 5 - Kayma merkezinin değişimi

\begin{tabular}{|c|c|c|c|c|c|}
\hline \multirow[b]{2}{*}{ Model Adı } & \multirow{2}{*}{$\begin{array}{c}\text { Teorik } \\
\text { Kayma } \\
\text { Merkezi } \\
\text { (e), m }\end{array}$} & \multicolumn{4}{|c|}{ SEM Kayma Merkezi } \\
\hline & & $\begin{array}{c}\text { \%0,5 } \\
\text { Ötelenme } \\
\text { Oranı }\end{array}$ & $\begin{array}{c}\% 1 \\
\text { Ötelenme } \\
\text { Oranı }\end{array}$ & $\begin{array}{c}\% 1,5 \\
\text { Ötelenme } \\
\text { Oranı }\end{array}$ & $\begin{array}{c}\% 2 \\
\text { Ötelenme } \\
\text { Oranı }\end{array}$ \\
\hline Model 1 & \multirow{6}{*}{$\underset{\sim}{\stackrel{\sim}{\sim}}$} & 1,2440 & 1,2441 & 1,2442 & 1,2445 \\
\hline Model 2 & & 1,2441 & 1,2446 & 1,2447 & 1,2460 \\
\hline Model 6 & & 1,2557 & 1,2657 & 1,2752 & 1,2874 \\
\hline Model 3 & & 1,2504 & 1,2515 & 1,2526 & 1,2535 \\
\hline Model 7 & & 1,2512 & 1,2611 & 1,2665 & 1,2725 \\
\hline Model 8 & & 1,2489 & 1,2542 & 1,2523 & 1,2478 \\
\hline
\end{tabular}

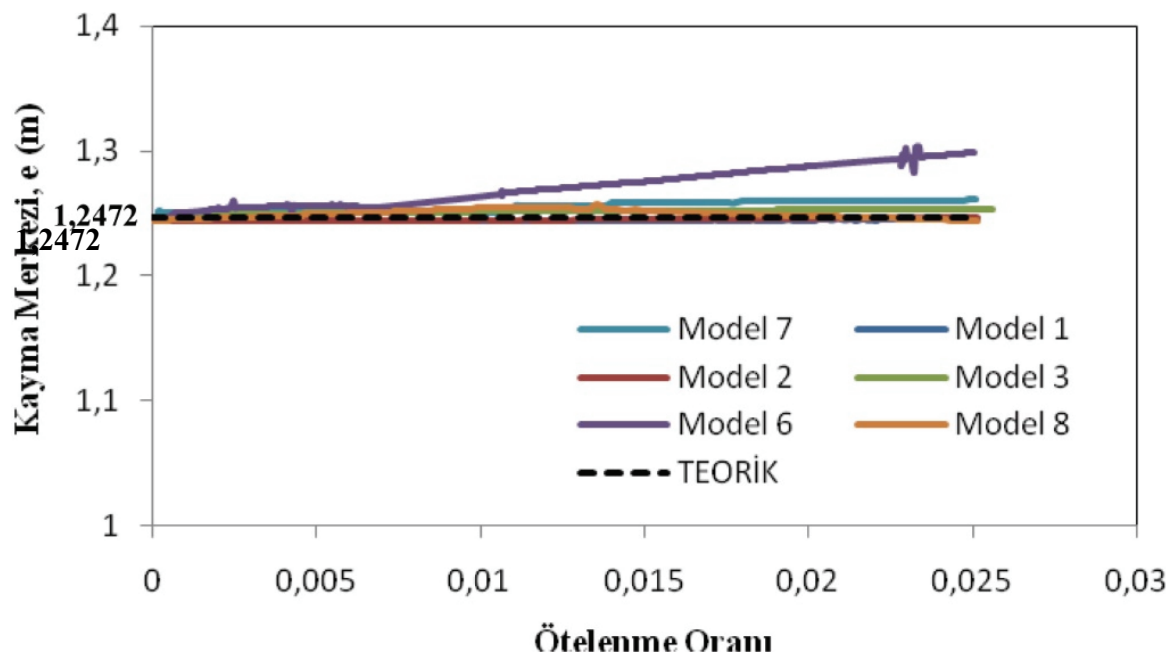

Şekil 30 - Kayma Merkezi-Ötelenme Oranı İlişkisi

\section{SONUÇLAR}

$\mathrm{Bu}$ çalışmada $\mathrm{U}$ şekilli betonarme perdelerde farklı yön ve değerlerdeki yatay yüklerin etkisi altında yapılan doğrusal olmayan analizlerin neticesinde meydana gelen deformasyon şekilleri araştırılmış, tasarımı etkileyen faktörler belirlenmiştir. Araştırmada sonlu eleman metodu kullanılarak modellenen perdelerin ANSYS yazılımında doğrusal ötesi analizleri yapılmış, elde edilen veriler SAP2000 programında yapılan kesit analizleri ile karşılaş̧ırılmıştır. Araştırmada elde edilen bilgiler aşağıda açıklanmıştır.

Yalnız eğilme momenti etkisindeki U şekilli betonarme perdelerde (Model 6, Model 4 ve Model 9) doğrusal olmayan analizlerde meydana gelen deformasyon durumu, kesit analizi ile karşılaştırılabilirken, burulma momentinin de olduğu durumlarda kesit analizi perdedeki 
deformasyon durumunu yansıtmakta yetersiz kalmaktadır. Şekil değiştirmeden önce düzlem olan kesitin şekil değiştirdikten sonra da düzlem kalması hipotezi burulma momentinin olduğu modellerde geçerliliğini kaybetmektedir. Birim şekil değiştirme diyagramları incelendiğinde kesitte burulma momentinden dolayı çarpılma meydana gelmektedir. Bu nedenle kesit analizleri sadece eğilme etkisindeki perdeler için yapılabilmiştir.

U şekilli betonarme perdelerde uygulanan yatay yük kayma merkezinden uzaklaştıkça kesitte oluşan burulma momenti artar. Burulma momentinin artması kesitin eğilme momenti kapasitesini azaltır. Model 6'da yatay yük perdenin kayma merkezinden uygulandığı için burulma momenti oluşmaz, bu nedenle eğilme momenti kapasitesi Model 1 ve Model 2' ye göre daha yüksektir.

Burulma etkisinin olmadığı yalnızca eğilme momenti etkisindeki U şekilli perdelerde (Model 6, Model 4 ve Model 9) sonlu eleman metodu (SEM) ile ulaşılan eğilme momenti kapasitesi, kesit hesabı (KH)'dan elde edilen eğilme momenti kapasitesine kıyasla çok yakın ya da biraz düşük olarak elde edilmiştir. Düşük olmasındaki sebep sonlu eleman modellemesinde kullanılan Solid65 betonarme elemanının yük altında çatlama özelliğine sahip olması ve betonun çatlama davranışıdır.

Burulma etkisinin olmadığı perdeler için sonlu eleman metodu (SEM) ile elde edilen eğrilik değerleri kesit hesabı (KH) ile elde edilen eğrilik değerlerine kıyasla daha küçüktür. Yani; sonlu eleman metodu daha düşük süneklik kapasitesi vermektedir.

Burulma etkisinin olmadığı yalnızca eğilme momenti etkisindeki U şekilli perdelerde (Model 4 ve Model 9), perdeye etkiyen yatay yük, perdenin yatay yüke paralel doğrultudaki P1 ve P2 kolları tarafından eşit biçimde taşınmaktadır. Ancak burulma momentinin de etkili olduğu durumlarda, burulmanın yönüne bağlı olarak perde kol ve gövdesinin taşıyacağı kesme kuvvetleri değişim göstermektedir. Bu değişim sonlu eleman metodunda ölçülebilirken, kesit analizi ile belirlenememektedir.

U şekilli betonarme perdelerin farklı kesme kuvvetleri etkisi altında yapılan doğrusal ötesi analizlerinde de teorik durumda olduğu gibi perdenin kayma merkezi yeri değişmemektedir. Teorik olarak hesaplanan kayma merkezi yeri ile doğrusal olmayan analizlerde hesaplanan kayma merkezi yeri birbiri ile aynıdır. Şekil 30'da bazı model yüklemelerde kesitlerin kayma merkezlerinde görülen küçük değişikliklerin sebebinin sonlu eleman modelinde analiz sırasında yakınsama kriterine yapılan müdahaleden dolayı olduğu düşünülmektedir.

Doğrusal olmayan durumda uygulanan kesme kuvveti etkisinde meydana gelen eğilme ve burulma etkilerinden dolayı kesit geometrisi değişmesine rağmen kayma merkezi teorik durumda olduğu gibi sabit kalmaktadır. Buna göre kayma merkezi kesitin eğilme ve burulma davranışına bağlı olmayan bir konumdur.

\section{Semboller}

$A_{0} \quad$ Etkin yer ivme katsayısı

$A(T)$ Spektral ivme katsayısı

$B \quad$ Basınç bölgesi 
Ç Çekme bölgesi

$e \quad$ Kayma merkezinin perde gövdesine uzaklığ 1

$G \quad$ Perde ağırlık merkezi

I $\quad$ Bina önem katsayıs

$I_{x} \quad \mathrm{x}$ yönündeki atalet momenti

KS Kesit hesab1

$\ell_{u} \quad$ Perde uç bölgesinin uzunluğu

$\ell_{w} \quad$ Perdenin toplam uzunluğu

$M \quad$ Perde moment kapasitesi

$M_{b} \quad$ Burulma momenti

$N \quad$ Normal (eksenel) Kuvvet

$R \quad$ Taşıyıcı sistem davranış katsayısı

$R_{a} \quad$ Deprem yükü azaltma katsayısı

SEM Sonlu eleman metodu

$S C \quad$ Perde kayma merkezi

$S(T) \quad$ Spektrum katsayıs1

$T_{A}, T_{B}$ Spektrum karakteristik periyodları

$T_{1} \quad$ Doğal titreşim periyodu

$V \quad$ Perdeye etki eden kesme kuvveti

$V_{t} \quad$ Toplam eşdeğer deprem yükü

$W \quad$ Bina toplam ağırlığ

$\varepsilon \quad$ Birim şekil değiştirme

$\varepsilon_{s} \quad$ Donatı çeliği birim şekil değiştirmesi

$\varepsilon_{c} \quad$ Beton birim şekil değiştirmesi

$\omega^{\circ} \quad$ Burulmada dönme açısı

$\phi_{u} \quad$ Maksimum eğrilik

$\phi_{y} \quad$ Akma anındaki eğrilik 


\section{Kaynaklar}

[1] Celep Z., Betonarme Taşıyıcı Sistemlerde Doğrusal Olmayan Davranış ve Çözümleme, İstanbul Teknik Üniversitesi, 2008.

[2] Beyer K., Dazio A., Priestley M.J.N., Quasi-static cyclic tests of two u shaped reinforced concrete walls, Journal of Earthquake Engineering, 12(7), 1023-1053, $2008 b$.

[3] Brueggen B., Waugh J., Aaleti S., Johnson B., French C., Sritharan S., Nakaki S., Tests of structural walls to determine deformation contributions of interest for performancebased design, Structural Engineering Research, (249), 6, 1-16, 2007.

[4] ACI 318-02, Building Code Requirements for Structural Concrete and Commentary, American Concrete Institute, Detroit, Michigan, 2008

[5] Maruta M., Suzuki N., Miyashita T., Nishioka T., Structural capacities of H-shaped RC core wall subjected to lateral load and torsion, 12WCEE2000, 2000.

[6] Wallace J.W., Moehle J.P., Ductility and detailing requirements of bearing wall building, ASCE Journal of Structural Engineering, 118(6), 1625-1644, 1992.

[7] İlgün A., Atımtay E., Çok katlı betonarme panel yapıların yatay yük altında davranış1: teorik ve deneysel araştırma, Selçuk Üniversitesi Mühendislik, Bilim Ve Teknoloji Dergisi, 22(4), 11-28, 2007.

[8] Ormancı D.D, Saygun A.I., Betonarme perdeli sistemlerin itme analizi için özelleşmiş yeni bir sonlu eleman, Pamukkale Üniversitesi Mühendislik Bilimleri Dergisi, 22(3), 142-153, 2016.

[9] DBYBHY, Deprem Bölgelerinde Yapılacak Binalar Hakkında Yönetmelik, 2007.

[10] Mander J.B., Priestley M.J.N., Park R., Observed stress-strain behaviour of confined concrete, Journal of Structural Engineering, 114 (8), 1827-1849, 1988.

[11] Saatcioglu M., Razvi S.R., Strength and ductility of confined concrete, Journal of Structural Engineering, 118 (6), 1590-1607, 1992.

[12] Kazaz İ., Gülkan P., Süneklik düzeyi yüksek betonarme perdelerdeki hasar sınırları, İMO Teknik Dergi, 387, 6113-6140, 2012.

[13] Ersoy U., Özcebe G., Betonarme, Evrim Yayınevi, İstanbul, 59, 2001.

[14] Bakioğlu M., Cisimlerin Mukavemeti, Beta Yayınevi, İstanbul, 2001. 